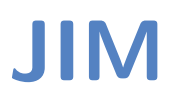

ISSN: 2183-0606

(CC BY 3.0)

Vol. 9, 3 (2021)

p. $27-57$

AM: Oct $/ 2021$

SM: May $/ 2021$

\title{
The Impact of Innovation Type on Financial and Non-financial Performance of SMES. A Scoping Review
}

\author{
Kaoutar Jamai ${ }^{1}$, Hans De Steur ${ }^{2}$, Ali Abidar ${ }^{3}$, and Xavier Gellynck ${ }^{4}$ \\ ${ }^{1}$ Department of Agricultural Economics, Ghent University, Coupure Links 653, 9000 Gent, Belgium | \\ Kaoutar.jamai@UGent.be \\ ${ }^{2}$ Department of Agricultural Economics, Ghent University | hans.desteur@UGent.be \\ ${ }^{3}$ Department of Rural Development Engineering, National School of Agriculture (Morocco) | \\ aabidar@enameknes.ac.ma \\ ${ }^{4}$ Department of Agricultural Economics, Ghent University | xavier.gellynck@UGent.be
}

\begin{abstract}
To take advantage of existing opportunities in a market of global competition and rapid changes, firms try to adapt their strategy by introducing new or improved innovation types. While there is a large body of literature investigating the relationship between innovation and performance, there is a need to further analyze the role of innovation type on performance, especially in SMEs. Using a scoping review approach, this study aims to evaluate the influence of innovation types on firm performance in SMEs. A total of 47 studies were selected to examine the correlation between innovation type and performance, and identify the key factors that strongly impact the firm growth per industry. Findings demonstrate the difference in innovation impact according to the targeted industrial sector and show which type could be more beneficial to enhance firm performance. In the most studied industries, results reveal that product innovation influences strongly firm performance in the manufacturing sector, while marketing and product innovation are the variables that most impact the growth of agro-food firms. Similarly, organizational and product innovation affect highly firm improvement in the manufacturing and service sectors. This study helps managers in their struggle to obtain growth by targeting the most appropriate dimensions of innovation and helps policy makers by making decisions that stimulate firm development.
\end{abstract}

Keywords: Innovation types; Firm performance; SME; Industry.

Cite paper as: Jamai, K.M., De Steur, H.R., Abidar, A.I., Gellynck, X., (2021). The Impact of Innovation Type on Financial and Non-financial Performance of SMES. A Scoping Review, Journal of Innovation Management, 9(3), 27-57.; DOI: https://doi.org/10.24840/2183-0606_009.003_0003

\section{Introduction}

Nowadays, innovation is one of the main concepts that has sparked the interest of researchers, managers and policymakers as a key driving force of firms' success (Bach, Dalazen, da Silva, Ferraresi, \& da Veiga, 2019; Chatzoglou \& Chatzoudes, 2018; Shouyu, 2017). Innovation is considered a key factor for every company that wants to stay competitive in the marketplace by exploring new opportunities and developing new products, services or strategies to ensure success (Chen, 2017; lonescu \& Dumitru, 2015; Urbancova, 2013), and to reach and sustain a competitive advantage(Lichtenthaler, 2020). Seeking for competitive advantages in a dynamic market, companies have increased the attractiveness around the undeniable importance of innovation, which in turn has enhanced the academic interest in its impacts (Herrera, 2016). 
Over time, innovation has undergone several changes in its classification. In early studies, innovation was based on new products, new production processes, new materials and resources, new markets, and new organizational forms (Manual, 1997a; Manual, 1997b). Other authors proposed a typology of managerial (Damanpour, 1991), marketing (Higgins, 1995; Manual, 2005) or organizational innovations (Huiban \& Bouhsina, 1998; Manual, 2005). The core of those innovation types is the conversation of new knowledge which in turn may improve performance to better answer market challenges (Guan \& Pang, 2017; Tuan, Nhan, Giang, \& Ngoc, 2016).

During the past years, there has been a growing interest in understanding and assessing the effect of innovation on firm performance in different sectors (Bigliardi, 2014). Previous studies have taken on the challenge of examining innovation indicators that have an important effect on the firms' development and lead to faster growth, particularly in SMEs (Ndalira, Ngugi, \& Chepkulei, 2013). They emphasized the effect of internal resources and external environment on business performance, with differences according to company size (Beyene, Shi, \& Wu, 2016; Ndesaulwa \& Kikula, 2016) and industry (Makanyeza \& Dzvuke, 2015; Shouyu, 2017). By taking into account their special characteristics and the specificity of each industrial sector, researchers have shown the importance of innovation in improving firms' growth and competitiveness at both national and international levels (Birchall, Carnegie, Draimin, Elkington, \& Love, 2014). They shed light on their flexibility to generate organizational changes and be more innovative than large firms (Manual, 2019; Spithoven, Vanhaverbeke, \& Roijakkers, 2013) when they are engaged in innovation as they explore opportunities and generate growth (Forth \& Bryson, 2018; Hossain, 2015).

The literature on SMEs underlines the need for innovation development, and the needs for creating customer value, attaining growth and sustaining competitiveness (Rexhepi 2014). Due to their importance in the business ecosystem, a comparative of studies in developed and developing countries was suggested (Rexhepi 2014) to examine the effect of innovation on performance by taking into account the relevance of SMEs' characteristics, such as industry.(Gatautis, Vaiciukynaite, \& Tarutè, 2019; F. J. Lin, Chen, \& Lo, 2014; Makanyeza \& Dzvuke, 2015). The aim is to determine and clarify differences and similarities across industries. Owing to the prominence of SMEs in domestic economies, such studies would enhance the understanding of their functioning to formulate strategies that answer their needs according to their activity sector, and consequently, protect SME development (Norrman \& Bager-Sjögren, 2010).

Accordingly, a scoping review approach is taken to compile and compare existing evidence on the impact of innovation types on SME firm performance across industries. We focus on both technological (product, process) and non-technological (marketing, organizational) innovation, as organizational and marketing innovations were often neglected (Günday, Ulusoy, Kılıç, \& Alpkan, 2011). The first and second edition of the Oslo Manual, for instance, only targeted product and process innovations (Manual, 1992, 1997a; Manual, 1997b). Although the last Manual of the Statistical Office of the European Communities (OECD) evoked the definitions of marketing and organizational innovations, the definitions are still underdeveloped compared to product and process innovations (Manual, 2005). Furthermore, the latest review studies were concentrated on the innovation-performance relationship regardless of the industry sector (Ndesaulwa \& Kikula, 2016; Shouyu, 2017), or focused only on firms in the same industry where firms tend to act similarly (e.g. manufacturing or, service) (Becheikh, Landry, \& Amara, 2006; Kolluru \& Mukhopadhaya, 2017; Rubera \& Kirca, 2012) instead of comparing industrial sectors.

As a result, the main fundamental questions in this perspective are (1) If SMEs are innovative, then which innovation types are mostly used by researchers to analyze the innovation-performance relationship across industries? And how can they differ from one industry to the other? (2) Whether 
the influence is significant, which innovation dimensions strongly impact SMEs' performance in each industry? (3) Are there some similarities or differences between the studied industries? The main purpose of this research is to analyze the influence of technological (product and process) and non-technological (marketing and organizational) innovation on financial and non-financial performance across industries in developed and emerging economies. Previous studies have shown that the impact of innovation on performance differs from one industry to another (Guan \& Pang, 2017; Makanyeza \& Dzvuke, 2015; Prifti \& Alimehmeti, 2017). In this regard, this paper provides several contributions. First, it is one of the first studies dealing with the role played by the industry sectors in affecting the relationship between innovation and firm performance. In fact, this study aims to analyze and assess this relationship by conducting a scoping review and offering a comprehensive and robust framework explaining the differences and similarities noticed between industries. Second, this study complements previous studies by enriching the innovation literature (Alegre, Sengupta, \& Lapiedra, 2013; Guan \& Pang, 2017; Tavassoli, 2015). It addresses this gap and sheds light on this relationship by clarifying and defining the effect on the company's performance. It also adds to the current body of knowledge by comparing high- and low-innovative companies based on industry differences. And it contributes to management practice by simultaneously addressing firm characteristics that drive performance. Indeed, appropriate methods can contribute to a significantly better understanding of innovation. Third and finally, analyzing innovation impacts contribute to our understanding of the innovation type needed to increase firm performance in each industry and explain in which contexts innovation can be beneficial. Indeed, this study helps managers, academics and policymakers to determine the adapted type of innovation needed in their industry of interest so as to ensure a high firm growth to sustain competitiveness. It opens up the opportunity to select the most strongest dimensions to take advantage of their added value. This paper also offers a detailed framework focusing on the less-examined types of innovation in order to further study their effects and confirm new insights on how they can affect business performance.

To meet the above objective, this article is organized as follows. In the second section, the concept of innovation is defined and a brief review of the literature on the relationship between innovation and performance through industry is presented. The research methodology is described in the third section by giving details of search strategy and selection approach. The fourth section introduces the findings followed by the fifth section, which analyses and discusses the obtained results. In the final section conclusions, research implications, limitations, and research directions are provided.

\section{Literature review}

Over the last twenty years, global competition became increasingly tough, forcing businesses to seek new strategies and creative approaches, especially in innovations. Due to the faster changes, businesses have started introducing and assessing their innovation strategies and their adoption capacity in order to gain a competitive position (Lichtenthaler, 2020). With the purpose of driving newness into the economic area, innovation is perceived as a mechanism of change adopted by firms to turn opportunities into creative ideas through cultivating efforts to ensure a continuous productivity improvement and consequently a sustained success value (Allahar, 2019; Beyene et al., 2016). Innovation was defined by Oslo Manual (Manual, 2005) as "the implementation of a new or significantly improved product (good or service), or process, a new marketing method, or a new organizational method in business practices, workplace organization or external relations". In fact, innovation is considered to be the transformation of knowledge to added value by increasingly 
influencing firms profitability and efficiency (Bach et al., 2019; Günday et al., 2011; Mai, Van Vu, Bui, \& Tran, 2019). It is a key driver of success and sustainable competitive advantage in the global market (Cành, Liem, Thu, \& Khuong, 2019) and used as a strategic source for firms to adopt in order to survive in a vying environment (Naoui-Outini \& El Hilali, 2019; Ortiz-Villajos \& Sotoca, 2018). However, to ensure a continuous development that leads to improving growth, innovation depends on firms' propensity and receptivity to select and adopt the right approaches and ideas (Martins, Abreu, \& Calado, 2018; Rubera \& Kirca, 2012).

The impact of innovation on firm performance was studied by several researchers. However this link remains a subject of debate since extant literature has identified not only a significant and positive relationship (Bigliardi, Ferraro, Filippelli, \& Galati, 2020; Cành et al., 2019; Ho, Nguyen, Adhikari, Miles, \& Bonney, 2018; Prifti \& Alimehmeti, 2017; YuSheng \& Ibrahim, 2020) but also negative or non-effects of innovation. The literature has identified several factors that may be behind this difference. Indeed, the effects of innovation differ according to the innovation type used to assess the firm performance, whether it is technological (process and product) or non-technological (organizational and marketing) (Günday et al., 2011; Vasconcelos \& Oliveria, 2018), radical or incremental (Forsman \& Temel, 2011), as well as type of industry (Bach et al., 2019; Enjolras, Camargo, \& Schmitt, 2019; Prifti \& Alimehmeti, 2017).

As to what determines the innovation-performance variations at the firm level, a considerable body of literature points to industry differences (Bach et al., 2019; Guan \& Pang, 2017; Prifti \& Alimehmeti, 2017). According to Kotha and Nair (1995), industrial characteristics of Japanese firms produce a strong impact on business performance. Spanos and Lioukas (2001) observed a high importance of industry type and firm specific influences on firm performance; however, they emphasized that both of them explain different dimensions of performance. F. J. Lin et al. (2014) indicated that in long-term competitive advantages, industry effects appear to be more significant than company factors. Furthermore, Makanyeza and Dzvuke (2015) employed data from businesses in Zimbabwe and concluded that firms in all industry categories studied are innovative; however, their performance has increased differently during the period in which firms were innovating. By analyzing the relationship between innovation and performance across industries in the emerging economy, Geldes, Felzensztein, and Palacios-Fenech (2016) study's revealed that firms have to implement various strategies to improve their performance depending on their economic sector. The results showed that product innovation is the only factor that affects the firm performance in all the industries studied. While non-technological innovations are those that are focusing on optimizing the performance of some specific sectors. In the same vein, Bach et al. (2019) highlighted that the innovation impacts vary depending on the sector, with some being more intense contributing consequently to the economic growth and knowledge transfer.

The significant effect of industrial characteristics on the innovative capacity of firms is broadly accepted in the literature. Regarding technological dynamism, some studies identified that traditional industries are less innovative than high-tech industries since they have fewer people dedicated to R\&D (Costa, Cabral, Forte, \& Costa, 2016; Enjolras et al., 2019). Other studies confirmed that a firm's ability and strategy to innovate varies according to the sector to which the firm belongs (Belotti, Santos, \& Basso, 2019; Zawislak, Gamarra, Alves, Barbieux, \& Reichert, 2014). Product and process innovation focused on technology acquisition are more prevalent in services and high-technology firms (Tether \& Tajar, 2008). The same conclusions were deduced by Prifti and Alimehmeti (2017) while comparing the performance of service and manufacturing firms. They found that service firms are more innovative than production ones. The results confirmed that production businesses tend to have less innovation due to a limited internal source 
of innovation such as R\&D.

The main purpose of this paper is to assess how the innovative-performance relationship of firms are affected by the industrial categories. From the angle of the industrial organization economics, the industry is considered as an important factor in predicting the company's behavior and conduct (F. J. Lin et al., 2014; Tan, 2016). A reciprocal relationship between firms' activity and the external contexts has been identified by earlier studies, where the industry in which companies are active is one of contexts for using innovation (Tavassoli, 2015). Therefore, industry categories tend to shape the innovative conduct of the company, which then simultaneously affect its innovation performance (Guan \& Pang, 2017).

\section{Methods}

This paper uses a scoping review methodology which differs from traditional narrative review. According to Munn et al. (2018), this approach allows one to exhaustively examine the literature by determining the available evidence (quantitative and/or qualitative etc.) and identifying how the research was conducted on a particular topic. It provides evidence by analyzing knowledge gaps and summarizing results from available data with a specific period based on a rigorous and transparent process (Arksey \& O'Malley, 2005; Peters et al., 2015). The general purpose of conducting a scoping review is also to map the key concepts, clarify working definitions and inform future research and practice in the field (Tricco et al., 2016). It provides a clear indication of the volume of available literature related to a specific topic and gives a detailed or broad overview of its focus (Munn et al., 2018).

As the narrative review is mainly descriptive and informative, it is often criticized for the use of personal and selection bias (Becheikh et al., 2006). In fact, the transparency of the process is one of the main differences between narrative and scoping review. The source and selection of studies used in the narrative review are usually not specified and evidence comes from limited articles to obtain a broad perspective on statements being made in the selected studies (Riaz, 2016). While the aim of a scoping review is to address the gap by identifying a prior review protocol allowing an explicit and transparent search methodology to synthesize findings, the narrative review remains general, lacking a clear methodology and protocol and with high risk of bias assessment (Munn et al., 2018; Tricco et al., 2018).

Several studies have used the scoping review in their research for the goal of analyzing and examining the nature, range or size of available evidence to explore the scope of literature on a specific topic (Gardner et al., 2018; King \& Grobbelaar, 2020). It is considered as an appropriate method to be adopted especially when the topic has been studied in multiple academic fields such as the case of innovation (van Niekerk, Manderson, \& Balabanova, 2021) and deemed to be suitable for obtaining an overview of existing research (Armstrong, Hall, Doyle, \& Waters, 2011; Spies, Grobbelaar, \& Botha, 2020). The scoping review also serves to examine and synthesize the coverage of the literature through a mapping of evidence and an identification of knowledge gaps and what should be explored (Arksey \& O'Malley, 2005; Munn et al., 2018; Ratshidi, Grobbelaar, \& Botha, 2020), which makes it a relevant method for this study.

Preferred Reporting Items for Systematic Reviews and Meta-Analyses (PRISMA) is an evidence based minimum reporting process. Its extension for Scoping Reviews outline essential reporting items was followed for this review. The research methodology is based on three stages: (1) developing the search strategy (2) defining the inclusion and exclusion criteria and finally, (3) selecting studies (Cacchione, 2016; Pham et al., 2014). 


\subsection{Search strategy}

Prior studies investigating the relationship between innovation type and business performance in different industries were examined to identify keywords operationalized for search presented in the literature review (Klewitz \& Hansen, 2014; Kolluru \& Mukhopadhaya, 2017; Sethibe \& Steyn, 2015). Similarly, keywords for the search related to innovation were deduced from OECD definition of innovation type. A total of 33 keywords were used through four clouds including innovation (e.g. innovation type, improvement, enhancement, diffusion, product/process improvement), performance (e.g. growth, turnover, income, financial non-financial development), SMEs (e.g. small business, medium firm) and industry. Studies were filtered using a combination of keywords and each combination must have at least one keyword that matches the targeted article to be selected. Articles were identified through Web of Science, ScienceDirect (Elsevier), Springer link (MetaPress), AgEcon search, and Google Scholar databases.

The period selected for this analysis was from 2000 to 2018 . The lower limit of the temporal horizon is justified by the lack of attention paid to data sources and analysis by the end of the 1990s. The beginning of the 2000s experienced a big change in terms of the applications of analytical models. It has had more in-depth research with economic and econometric analysis and the introduction of firm-level surveys (Becheikh et al., 2006; Kolluru \& Mukhopadhaya, 2017).

Table 1. Keywords search strategy

\begin{tabular}{|c|c|c|c|c|}
\hline Innovation & Performance & SME & Industry & Example of a search string \\
\hline $\begin{array}{l}\text { Innov*, innovation } \\
\text { type, } \\
\text { improvement, } \\
\text { enhancement, } \\
\text { diffusion, } \\
\text { product/process } \\
\text { improvement, } \\
\text { eco* innovation, } \\
\text { Market- } \\
\text { ing/organizational } \\
\text { strategy, product } \\
\text { stewardship, } \\
\text { product/process } \\
\text { development, } \\
\text { creat*, } \\
\text { innovativeness }\end{array}$ & $\begin{array}{l}\text { Perform*, } \\
\text { growth, } \\
\text { turnover, } \\
\text { income, } \\
\text { financ*/non- } \\
\text { financial } \\
\text { development, } \\
\text { output, } \\
\text { return (ROA, } \\
\text { ROI, ROS, } \\
\text { ROE) }\end{array}$ & $\begin{array}{l}\text { Small/medium } \\
\text { business, } \\
\text { small and } \\
\text { medium- } \\
\text { sized business, } \\
\text { small/medium } \\
\text { firm, SME. }\end{array}$ & Industry* & $\begin{array}{l}\text { =(Innov* OR innovation type } \\
\text { OR product improvement OR } \\
\text { process improvement OR eco* } \\
\text { innovation OR Marketing } \\
\text { strategy OR organizational } \\
\text { strategy OR product } \\
\text { stewardship OR product } \\
\text { development OR process } \\
\text { development OR } \\
\text { innovativeness) AND (Perform* } \\
\text { OR growth OR turnover OR } \\
\text { income OR finance* } \\
\text { development OR non-financial } \\
\text { development OR output OR } \\
\text { return) AND (Small business } \\
\text { OR medium business OR small } \\
\text { and medium-sized business OR } \\
\text { small firm OR medium-firm OR } \\
\text { SME) AND (Industr*) }\end{array}$ \\
\hline
\end{tabular}

Note : based on Klewitz and Hansen (2014); Sethibe and Steyn (2015).

\subsection{Inclusion and exclusion criteria}

Four inclusion criteria were used for selecting relevant studies. First of all, only papers dealing with innovation types, namely, technological innovation (product/process) related to the adoption of new or significantly improved goods and services or/and production and logistic methods, and non-technological innovation (marketing, organizational) based on the establishment of new or significant change on methods related to consumer and the mix marketing or/and business strategies and workplace approach (Manual, 2005), were included. Secondly, solely papers analyzing the relationship between innovation and performance of the firm were selected. These analyses 


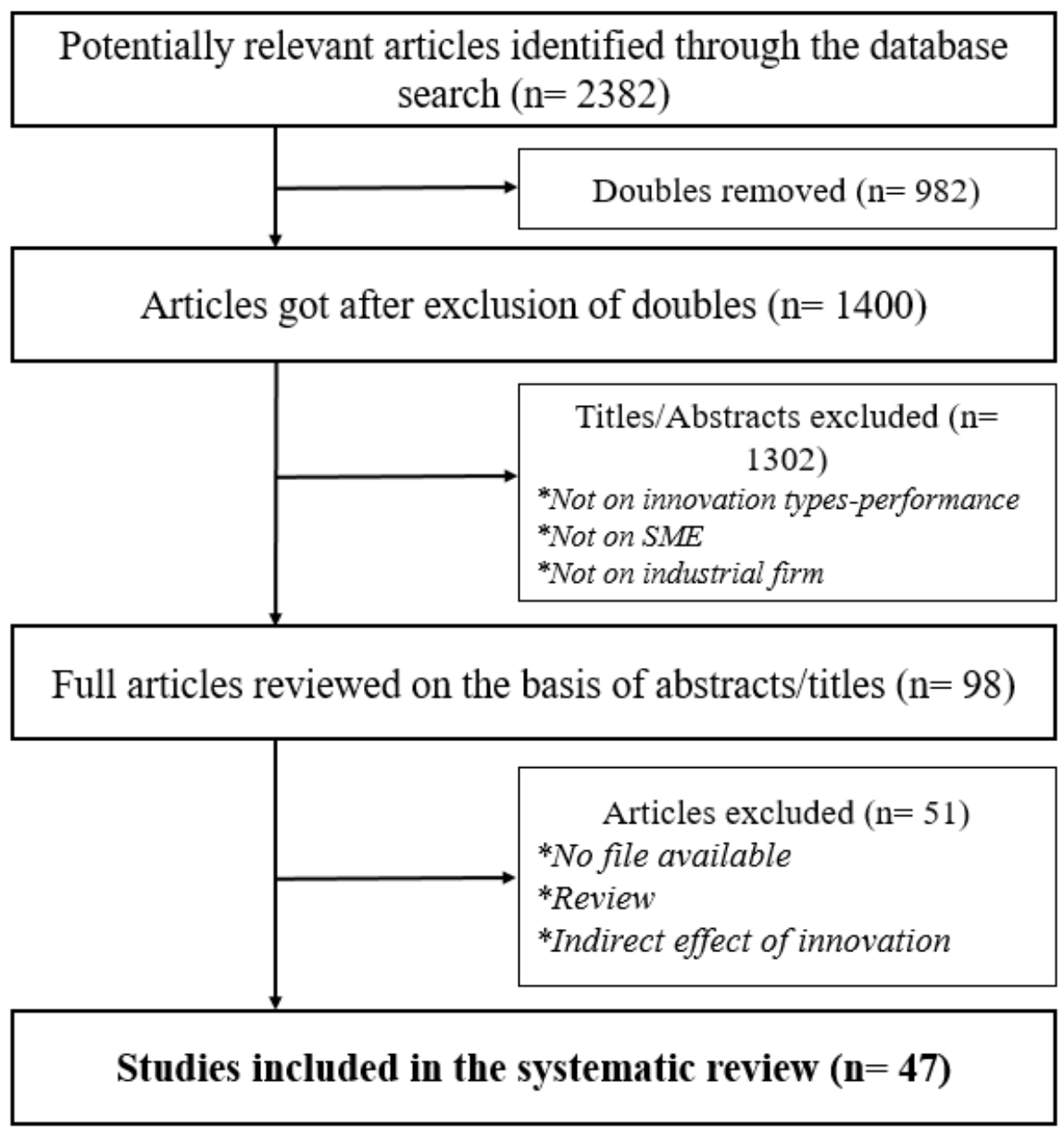

Figure 1. Flowchart describing the article selection process and results.

need to be carried out at the level of SMEs with a sample of firms belonging entirely or mainly to an industrial sector. In this context, articles dealing with large firms or a mixture of firms without any specification or comparison between them based on size were also removed. Thirdly, a clearly defined measure should have been reported. Consequently, theoretical, conceptual and case-study approaches were not selected to allow proper comparability. Fourthly, the study should be published in a peer-reviewed journal between 2000 and 2018.

\subsection{Study selection}

The initial search led to 2382 articles. The number of papers was then reduced to 1400 by removing all the doubles across different databases. In the second step, the identified articles were subjected to a double screening (title and abstract) to ensure that only articles dealing with the relationship between innovation types and SME firm performance were selected.

Finally, a full review of papers was conducted, which left a total of 47 studies on the innovation type-performance relationship. Articles covering another aspect (side) of innovation or not dealing with a direct relationship between innovation types and performance were not selected. Also articles that were not available (with just title or/and abstract) or not in English were excluded to keep studies that match all our inclusion criteria.

A Microsoft Excel database was designed to extract data from the studies, including the year 
of study and publication, research place, industry(s) type to which these firms belong, sample size, an analytical method applied for data, innovation types (i.e. product, process, marketing, organizational), performance indicators (financial, non-financial), and the (significance of the) effect of the relationship innovation on performance. This approach ensures a meaningful and rigorous comparison between the selected articles (De Man \& Duysters, 2005).

\subsection{Sample descriptive}

Figure 2 indicated that before 2010, few studies were interested in studying the effect of innovation on SMEs, with $23 \%$ of reviewed articles (on average, 2 articles per year). Since 2010 the number of articles began to increase gradually at an average of 4.5 articles per year and reached its peak in 2013 and 2015. This increase might be explained indirectly by the attention given to the SMEs innovators company and the launching of a set of strategies during the 2000s for the ultimate goal of promoting the development of innovative SMEs as the engine of the economy (Robson, Haugh, \& Obeng, 2009).

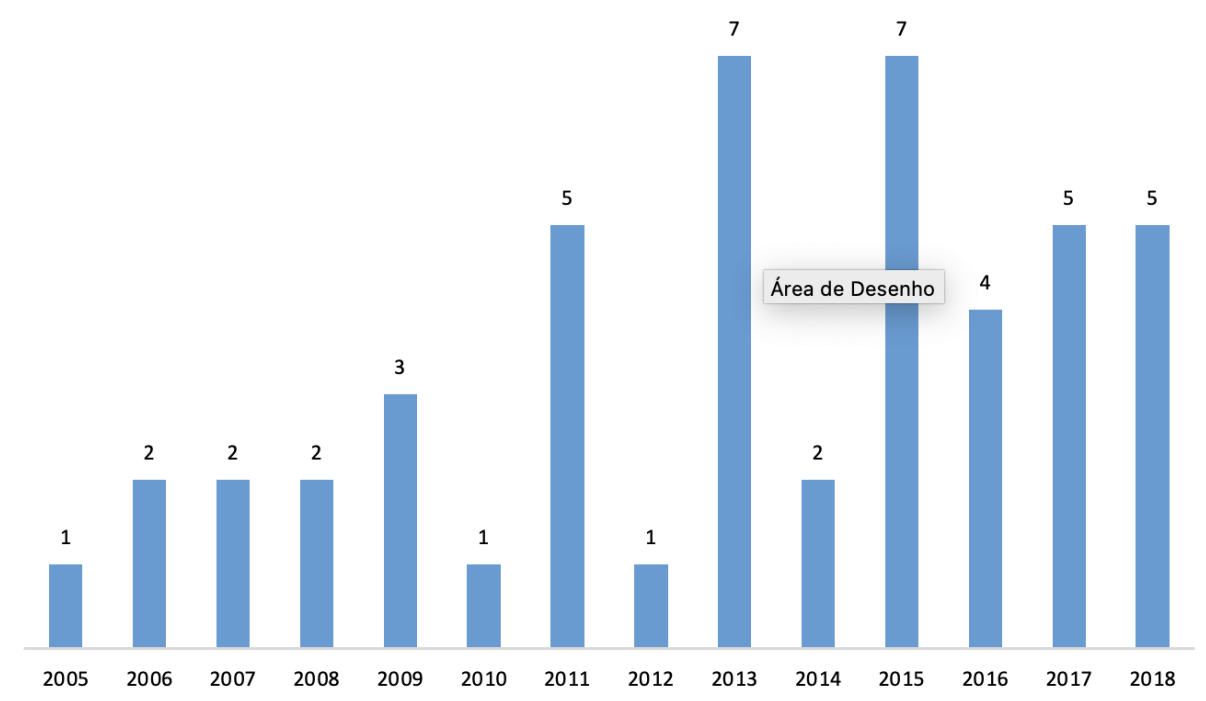

Figure 2. Number of articles per year.

Table 2 showed the distribution of targeted industries in the reviewed articles. Almost half of the papers looked at the manufacturing industry, either alone $(12$ articles $=26 \%)$ or in combination with the service industry $(6$ articles $=13 \%)$. This confirmed the interest and importance given to these two industries (Becheikh et al., 2006; Kolluru \& Mukhopadhaya, 2017). Moreover, eight articles focused on the agro-food industry $(18 \%)$, while 13 combined studies targeted several industries $(28 \%)$, among which manufacturing, construction, hi-tech producers, textiles \& wearing apparel, food and beverage, and furniture. It appeared that funders have been interested in research related to the manufacturing and/or services industries to the detriment of the rest, which explained their dominance in this field of research (39\%).

The same table depicted the distribution of articles per continent. It showed that half of the articles looked at Asia, followed by Europe (27\%) and Africa (10\%). This finding can be linked to the current orientation of policies and strategies developed by emerging countries to promote and stimulate economic growth through SMEs (Ndesaulwa \& Kikula, 2016).

Table 3 showed the distribution of studies according to the type of innovation, i.e. technological innovation (product and process) and non-technological innovation (marketing and organizational), 
Table 2. General characteristic of selected articles

\begin{tabular}{|c|c|c|c|}
\hline Characteristic & Category & Frequency & Percentage \\
\hline \multicolumn{4}{|l|}{ Industry type } \\
\hline & Manufacturing industry & 11 & $23 \%$ \\
\hline & Agrofood industry & 8 & $17 \%$ \\
\hline & $\begin{array}{l}\text { Manufacturing and service } \\
\text { industry }\end{array}$ & 6 & $13 \%$ \\
\hline & Software industry & 2 & $4 \%$ \\
\hline & furniture industry & 3 & $6 \%$ \\
\hline & Service industry & 1 & $2 \%$ \\
\hline & $\begin{array}{l}\text { Ceramic craft/ Stone } \\
\text { handicraft industry }\end{array}$ & 2 & $4 \%$ \\
\hline & Garment Industry & 1 & $2 \%$ \\
\hline & Varied industries & 13 & $28 \%$ \\
\hline \multicolumn{4}{|l|}{ Place $(*)$} \\
\hline & Asia & 25 & $49 \%$ \\
\hline & Europe & 14 & $27 \%$ \\
\hline & Africa & 5 & $10 \%$ \\
\hline & America & 4 & $8 \%$ \\
\hline & Australia & 3 & $6 \%$ \\
\hline \multicolumn{4}{|c|}{ Statistical and econometric analysis } \\
\hline & Regression & 29 & $62 \%$ \\
\hline & PLS-SEM & 4 & $9 \%$ \\
\hline & $\begin{array}{l}\text { structural equation model } \\
\text { (SEM) }\end{array}$ & 4 & $9 \%$ \\
\hline & Partial Least Square (PLSc) & 3 & $6 \%$ \\
\hline & Correlation & 1 & $2 \%$ \\
\hline & Others & 6 & $13 \%$ \\
\hline
\end{tabular}

$\left({ }^{*}\right)$ The total number is higher than 47 because some studies cover more than one country.

and performance, i.e. financial and non-financial performance. While $63 \%$ of the reviewed articles focused on technological innovation, only $21 \%$ were targeting non-technological innovation to examine the relationship between innovation and performance. This was confirmed by Günday et al. (2011), who emphasized that product and process innovations are the most evaluated types concerning this relationship. Product innovation was the most commonly studied innovation type (35\%). Two-thirds of the sample included product and process innovation. Marketing and organizational innovation were still understudied in innovation studies (Damanpour, 1991; Manual, 2005). Besides, $16 \%$ of the selected articles used innovation in a general way without specifying the type.

Regarding performance, financial indicators were reported in almost half of the reviewed studies. Thereby, researchers looked at variables like growth in sales, profitability, turnover, return on sales (ROS), return on equity (ROE), return on assets (ROA), net profit margin, and return on investment $(\mathrm{ROI})$ to demonstrate the link between innovation and performance. Non-financial indicators like innovative, market, production and organizational performance only cover $24 \%$ of the studies. This corresponded with Lumpkin and Dess (1996), who highlighted that in literature, financial measurement prevails. Nevertheless, ignoring the effect attributed by non-financial assets will hamper the innovation effectiveness evaluation (Hilmi, Ramayah, \& Mustapha, 2011). Hence, 
to measure a firm long term success, both financial and non-financial indicators should be included (Avci, Madanoglu, \& Okumus, 2011), indicating a clear gap.

Table 3. Percentage of Studies by Type of Innovation and performance

\begin{tabular}{lcc}
\hline Innovation indicators & Frequency & Percentage \\
\hline Technological innovation & $\mathbf{5 6}$ & $\mathbf{6 3 \%}$ \\
Product innovation & 31 & $35 \%$ \\
Process innovation & 25 & $28 \%$ \\
Non-technological innovation & $\mathbf{1 8}$ & $\mathbf{2 1 \%}$ \\
Marketing innovation & 11 & $13 \%$ \\
Organizational innovation & 7 & $8 \%$ \\
Innovation (Unspecified) & 14 & $\mathbf{1 6 \%}$ \\
\hline Total & $\mathbf{8 8}$ & $\mathbf{1 0 0 \%}$ \\
\hline Performance indicators & $\mathbf{A m o u n t}$ & $\mathbf{4 9 \%}$ \\
\hline Financial performance & $\mathbf{2 4}$ & $\mathbf{2 4 \%}$ \\
Non-financial performance & $\mathbf{1 2}$ & $\mathbf{2 7 \%}$ \\
Performance (Unspecified) & 13 & $\mathbf{1 0 0 \%}$ \\
\hline Total & $\left.\mathbf{4 9} \mathbf{( *}^{*}\right)$ & \\
\hline Note $\left.:{ }^{*}\right)$ As some indicators have been studied by the same articles, the total number of indicators studied \\
exceeds the number of articles. & &
\end{tabular}

To evaluate the effect of innovation, researchers had used several statistical and econometric methods (Table 2). Accordingly, almost two-thirds of the studies were based on regression analysis, mainly logistic regression analysis $(62 \%)$, to determine the role of innovation types. This is consistent with the findings of Becheikh et al. (2006) who confirmed that regression is the most widely analytical approach used for this measurement. Structural equation model (SEM) and PLS-SEM were each used in $9 \%$ of the studies. Partial Least Square and Correlation were hardly used ( 6 and $2 \%$ respectively). It is also important to point out that $20 \%$ of articles used a descriptive approach, either separately or jointly with advanced econometric analysis. Also, $12 \%$ of studies carried out other types of analysis, such as the Classification trees approach, Entropy measures or Comparative analysis.

\section{Results and discussion}

The examination of 47 articles in the scoping review raises a broad spectrum of issues related to innovation and its determinant. Based on the analysis of reviewed studies, a comprehensive framework is established and presented in Figure 3 in order to shed light on the most measured innovation dimensions to influence firm performance by clustering them into seven categories based on the industry type. The framework combines the firm's innovation aspects related to the industry studied while analyzing the influence of each innovation type on business performance. Numerous studies have highlighted the relevance of innovation as a catalyst of development and the strongest dimensions of it associated with the firm. In recent literature, the positive effects of industry type have been confirmed in a wide range of econometric studies, which play a significant role in determining innovation. A few studies have surprisingly combined multiple industries to provide insight into differences regarding firms behavior.

The determinant of innovation is categorized into seven groups in the present framework. It alludes to innovation types used by each industry to explain firm performance, as well as the influential indicators that highly impact the overall growth. The four types of innovation are 


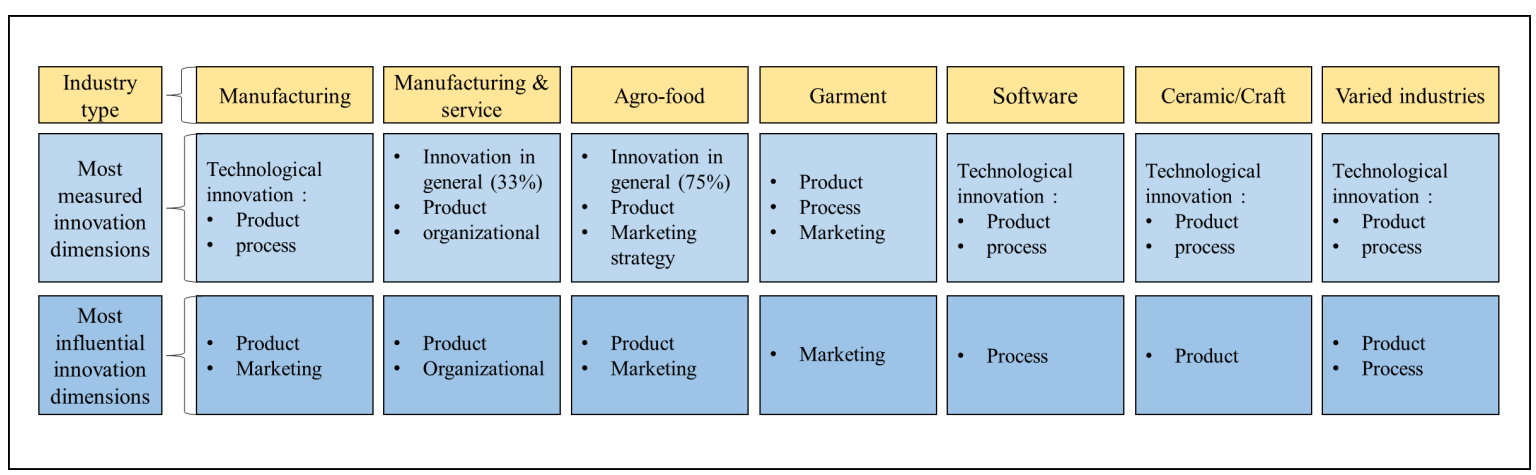

Figure 3. A framework of review finding.

identified and distributed by industry depending on the use and the strength of the effect. In these groups, existing contributions are explored and analyzed to reinforce the understanding of innovation by researchers and practitioners.

4.1. The impact of innovation on firm performance across industry

The examined papers tried to reinforce the existing research by analyzing different aspects of the innovation-performance relationship. To present our findings in line with the proposed framework, the outcomes of the examination are classified in two streams: (i) results related to the most measured innovation dimensions to influence firm performance (Table 4); (ii) results related to innovation dimensions highly influencing the performance (Table 5).

\section{Stream 1 : Most measured innovation types}

Manufacturing industry: For research on SMEs in the Manufacturing industry, more emphasis had been put on technological innovation (product \& process) as a source of firm growth, whereas non-technological innovation was hardly examined. In other words, researchers tend to measure the performance of firms based on product and process innovation to the detriment of other types (Ndalira et al., 2013). The focus on the impact of technological innovation, developing radical products and processes or improving existing ones can lead to competitive advantages, attract new customers, stretch external resources, and also open access to several markets (Romano, 1990; Wolff \& Pett, 2006; Zahra \& Nielsen, 2002). Besides, the use of performance remained general whilst including financial and non-financial variables. For example, Rosli and Sidek (2013) and Subrahmanya (2011) examined the effect of product and process innovation on SMEs' performance. Both studies confirmed that technological innovation strongly influences firms' performance with a higher impact of product compared to process innovation. Indeed, it is often emphasized that only through technological innovation, firms can achieve success and exploit their internal and external resources (Kallmuenzer \& Scholl-Grissemann, 2017). This approach is also following Hwang, Hwang, and Dong (2015), who confirmed that the complementarity between product and process innovation drives a stronger force that can lead to better performance (Auken, Guijarro, \& Lema, 2008). Roach, Ryman, and Makani (2016) and Wolff and Pett (2006) focused on product innovation and investigated how it can facilitate the achievement of positional advantages and consequently, firm growth. They reported empirical evidence on the significant positive impact of product innovation on SMEs' performance. Furthermore, O'Cass and Weerawardena (2009) and Boachie-Mensah and Acquah (2015) examined the relationship between innovation types and organizational performance. Their results demonstrated that both technological and non-technological innovation allows SMEs to gain a higher performance in the market. It appears that marketing and organizational innovation has not received enough attention from researchers 
in this sector (Günday et al., 2011). This is explained by the difficulty of measuring the effects of these two non-technological innovations in which the strategy and the human factor play a primordial role. In addition, SMEs are less active in marketing and organizational innovation activities compared to larger firms due to an insufficiency of a skill set throughout the process of creation-adoption-commercialization (Hinteregger, Durst, Temel, \& Yesilay, 2019). However, it is necessary to emphasize that their indirect effect on the launch of a new product or the adoption of an innovative process allows to ensure a superior performance of the company and an achievement of excellence.

Agro-food industry: The majority of studies in the Agro-food industry tended to use a general notion of innovation (75\%). Restricted studies have been concentrated on technological innovation and/or market innovation as determinants. Furthermore, it is worth mentioning that financial performance was also the key indicator of the reviewed articles in the agro-food industry. Ismanu, Salim, Moeljadi, and Aisjah (2017) stated that the financial indicators are the most used and preferred by the firm to measure performance due to measurement easiness. In fact, several studies revealed that radical product, process and market innovation are the main factors that firms can use to improve their annual sales turnover (Alam, Bhuiyan, Jani, \& Wel, 2016; Bhuiyan, Said, Ismail, Jani, \& Fie, 2016), with a stronger correlation between market innovation and performance (Haghighinasab, Sattari, Ebrahimi, \& Roghanian, 2013; Najib \& Kiminami, 2011). Indeed, researchers underlined that innovation leads to larger success (Nuryanti \& Andreas, 2018) when it is developed chiefly for increasing differentiation with competitors, creating new or improved technology/services to meet the customer's needs (Bigliardi, 2014), or when firms have significant brand awareness and take into account the customer experience (Vasconcelos \& Oliveria, 2018). In fact, limited studies in this area have looked at the effect of each type of innovation on improving firm performance. The majority have focused on an overall study of innovation, which remains imprecise and does not offer the necessary conclusions regarding the key success factors on which the firm can rely in order to be competitive in the market.

Manufacturing \& service industry: Studies on Manufacturing \& Service industry took a different approach as they studied separately or jointly technological and non-technological innovation, as also suggested in previous studies (Becheikh et al., 2006). Indeed, two out of six studies reported the effects of technological and non-technological innovation in general. The remaining studies selected only one innovation type, namely, product or organizational innovation. In line with preceding studies that lent support for a positive relationship between innovation types and firm performance, Meutia (2015) showed that product innovation influences marketing performance directly. This might be due to the fact that product development allows the organization to adapt and be part of market change as well as to stay competitive. Indeed, the type of innovation has a crucial role in determining firm performance in this sector (Della Torre \& Solari, 2011; Kasseeah, 2013). More specifically, organizational innovation seems to strongly enhance financial performance, which supports the focus on non-technological parameters (Della Torre \& Solari, 2011; Kim-Soon, Ahmad, Kiat, \& Sapry, 2017) taking into account the role that a well-structured and strategic organization of the company may perform to reinforce the growth. It should be noted that marketing and process innovation have been understudied in this sector, since the product is one of the most studied indicators, allowing to ensure the achievement of tangible results more easily and in a limited period of time, compared to the process or marketing where the implementation and adoption of strategies require time before achieving the first results.

Ceramic/stone craft, software \& garment industries: Although the number of studies was limited for ceramic/stone craft, furniture, garment, and software sectors, the trend remained similar. Indeed, product and process innovation was used as an indicator of performance in the 
majority of studies (89\%). While market and organizational innovation were involved only in $44 \%$ and $11 \%$ of the cases respectively. Those industries tend to use financial indicators to justify their performance. Studies carried out in the ceramic/stone craft industry showed that technological innovation has a significant effect on financial performance but the correlation coefficient is still stronger for the product compared to the process (Astuti, Prawoto, Irawan, \& Sugiono, 2018; Ismanu et al., 2017). Furthermore, the study conducted by Ismanu et al. (2017) indicated that product innovation is more frequently implemented as a business strategy for SMEs. Similarly, the software industry showed more links with technological innovation rather than non-technological innovation. Ndubisi and Agarwal (2014) found a positive relationship between product and process innovation in saving costs for SME performance. Contrarily, Ndalira et al. (2013) found that firm performance is better explained by non-technological innovation and marketing innovation particularly in the garment sector. Even if technological innovation did not significantly influence firm performance, research pointed to an indirect impact on firms through boosting sales.

Combined industries: Studies examining varied sectors industries tended to employ technological innovation instead of the market and organizational innovations. This is most likely because technological innovation is based on tangible variables that facilitate their measurement (Walker, Chen, \& Aravind, 2015). Furthermore, the performance indicator differed as the targeted industry differed. By studying different industries, Ar and Baki (2011) showed that technological innovation has provided a stronger impact on SME performance, especially for product innovation. Bartolacci, Castellano, and Cerqueti (2014) provided evidence that innovation types influence small firm performance when they invest in tangible and intangible assets. Similarly, Hilmi et al. (2011) found a significant correlation between product, process, market innovation, and financial and non-financial performance of SMEs in Malaysia. On the contrary, Oke, Burke, and Myers (2007), showed that incremental and radical innovation has a positive impact on business performance mainly, turnover, and growth in sales. However, it is important to note that the effect of incremental innovation is the strongest. Makanyeza and Dzvuke (2015), for example, investigated the influence of innovation on the performance of SMEs in three industrial sectors (manufacturing, services and agro-food). The results showed that innovation positively predicts firm performance for SMEs operating in the manufacturing and service industry. Furthermore, technological innovation (product and process) was found to influence the performance of manufacturing industries whereas organizational innovation better explains the performance of service firms. These results proved that the influence of innovation and its impact on firm growth differs according to the targeted industry.

Table 4. The main characteristic of reviewed articles distributed by industry

\begin{tabular}{l|c|c|c|c|c|c|c|c|c|c|c|l}
\hline Industry & \multicolumn{3}{|c|}{$\begin{array}{c}\text { The innovation } \\
\text { involved (*) }\end{array}$} & \multicolumn{2}{c|}{$\begin{array}{c}\text { Performance } \\
\text { indicators (*) }\end{array}$} & Country & $\begin{array}{c}\text { Year of } \\
\text { publication }\end{array}$ & Sample & References \\
\hline & Pd & Pr & Mr & Or & Uns & F. & N.F & Uns & & & & \\
\hline $\begin{array}{l}\text { Agro- } \\
\text { food }\end{array}$ & & & & & $\sqrt{ }$ & $\sqrt{ }$ & & & Malaysia & 2016 & 247 & $\begin{array}{l}\text { (Bhuiyan et } \\
\text { al., 2016) }\end{array}$ \\
\cline { 2 - 11 } & & & & & $\sqrt{ }$ & $\sqrt{ }$ & & & Malaysia & 2016 & 247 & $\begin{array}{l}\text { (Alam et al., } \\
\text { 2016) }\end{array}$ \\
\hline & $\sqrt{ }$ & $\sqrt{ }$ & $\sqrt{ }$ & & & $\sqrt{ }$ & & & Australia & 2006 & 87 & $\begin{array}{l}\text { (Bhaskaran, } \\
\text { 2006) }\end{array}$ \\
\hline & $\sqrt{ }$ & $\sqrt{ }$ & $\sqrt{ }$ & & & $\sqrt{ }$ & & & Indonesia & 2011 & 167 & $\begin{array}{l}\text { (Najib \& } \\
\text { Kiminami, } \\
\text { 2011) }\end{array}$ \\
\hline
\end{tabular}


Jamai, De Steur, Abidar, Gellynck

\begin{tabular}{|c|c|c|c|c|c|c|c|c|c|c|c|c|}
\hline \multirow[t]{2}{*}{ Industry } & \multicolumn{5}{|c|}{$\begin{array}{c}\text { The innovation } \\
\text { involved }(*)\end{array}$} & \multicolumn{3}{|c|}{$\begin{array}{l}\text { Performance } \\
\text { indicators }(*)\end{array}$} & \multirow[t]{2}{*}{ Country } & \multirow[t]{2}{*}{$\begin{array}{c}\begin{array}{c}\text { Year of } \\
\text { publication }\end{array} \\
\end{array}$} & \multirow[t]{2}{*}{ Sample } & \multirow[t]{2}{*}{ References } \\
\hline & Pd & $\operatorname{Pr}$ & $\mathrm{Mr}$ & Or & Uns & F. & N.F & Uns & & & & \\
\hline & & & & & $\sqrt{ }$ & & & $\sqrt{ }$ & Iran & 2013 & 116 & $\begin{array}{l}\text { (Haghighinasab } \\
\text { et al., 2013) }\end{array}$ \\
\hline & & & & & $\sqrt{ }$ & $\sqrt{ }$ & & & Italy & 2014 & 98 & $\begin{array}{l}\text { (Bigliardi, } \\
\text { 2014) }\end{array}$ \\
\hline & & & & & $\sqrt{ }$ & & & $\sqrt{ }$ & Brazil & 2018 & 55 & $\begin{array}{l}\text { (Vasconcelos } \\
\text { \& Oliveria, } \\
2018)\end{array}$ \\
\hline & & & & & $\sqrt{ }$ & $\sqrt{ }$ & & & Indonesia & 2018 & 108 & $\begin{array}{l}\text { (Nuryanti \& } \\
\text { Andreas, } \\
2018)\end{array}$ \\
\hline \multirow[t]{2}{*}{$\begin{array}{l}\text { Ceramic } \\
\text { craft }\end{array}$} & $\sqrt{ }$ & $\sqrt{ }$ & $\sqrt{ }$ & $\sqrt{ }$ & & & $\sqrt{ }$ & & Indonesia & 2018 & 81 & $\begin{array}{l}\text { (Astuti et al., } \\
2018 \text { ) }\end{array}$ \\
\hline & $\sqrt{ }$ & $\sqrt{ }$ & & & & $\sqrt{ }$ & & & Indonesia & 2017 & 26 & $\begin{array}{l}\text { (Ismanu et al., } \\
2017)\end{array}$ \\
\hline \multirow[t]{3}{*}{ Furniture } & $\sqrt{ }$ & $\sqrt{ }$ & $\sqrt{ }$ & & & $\sqrt{ }$ & & & Indonesia & 2017 & 150 & $\begin{array}{l}\text { (Karno \& } \\
\text { Purwanto, } \\
2017)\end{array}$ \\
\hline & $\sqrt{ }$ & $\sqrt{ }$ & $\sqrt{ }$ & & & $\sqrt{ }$ & & & $\begin{array}{l}\text { Italy, } \\
\text { Spain, } \\
\text { Finland }\end{array}$ & 2009 & 27 & $\begin{array}{l}\text { (Otero-Neira, } \\
\text { Tapio } \\
\text { Lindman, \& J. } \\
\text { Fernández, } \\
\text { 2009) }\end{array}$ \\
\hline & $\sqrt{ }$ & $\sqrt{ }$ & & & & & & $\sqrt{ }$ & Indonesia & 2015 & 55 & (Hajar, 2015) \\
\hline Garment & $\sqrt{ }$ & $\sqrt{ }$ & $\sqrt{ }$ & & & $\sqrt{ }$ & & & Kenya & 2013 & 31 & $\begin{array}{l}\text { (Ndalira et al., } \\
2013 \text { ) }\end{array}$ \\
\hline \multirow{6}{*}{$\begin{array}{l}\text { Manu- } \\
\text { facturing } \\
\& \text { service }\end{array}$} & $\sqrt{ }$ & $\sqrt{ }$ & $\sqrt{ }$ & & & & $\sqrt{ }$ & & Taiwan & 2007 & 877 & $\begin{array}{l}\text { (C. Y. Y. Lin } \\
\text { \& Chen, 2007) }\end{array}$ \\
\hline & $\sqrt{ }$ & & & & & & $\sqrt{ }$ & & Indonesia & 2015 & 200 & $\begin{array}{l}\text { (Meutia, } \\
\text { 2015) }\end{array}$ \\
\hline & & & & & $\sqrt{ }$ & $\sqrt{ }$ & & & Mauritius & 2013 & 123 & $\begin{array}{l}\text { (Kasseeah, } \\
2013)\end{array}$ \\
\hline & & & & & $\sqrt{ }$ & $\sqrt{ }$ & & & UAE & 2013 & 200 & $\begin{array}{l}\text { (Al-Ansari, } \\
\text { Pervan, \& Xu, } \\
2013)\end{array}$ \\
\hline & & & & $\sqrt{ }$ & & & & $\sqrt{ }$ & Italy & 2011 & 114 & $\begin{array}{l}\text { (Della Torre \& } \\
\text { Solari, 2011) }\end{array}$ \\
\hline & $\sqrt{ }$ & $\sqrt{ }$ & $\sqrt{ }$ & $\sqrt{ }$ & & & & $\sqrt{ }$ & Malaysia & 2017 & 43 & $\begin{array}{l}\text { (Kim-Soon et } \\
\text { al., 2017) }\end{array}$ \\
\hline \multirow[t]{2}{*}{$\begin{array}{l}\text { Manu- } \\
\text { facturing }\end{array}$} & $\sqrt{ }$ & $\sqrt{ }$ & $\sqrt{ }$ & $\sqrt{ }$ & & & $\sqrt{ }$ & & Ghana & 2015 & 243 & $\begin{array}{l}\text { (Boachie- } \\
\text { Mensah \& } \\
\text { Acquah, 2015) }\end{array}$ \\
\hline & $\sqrt{ }$ & $\sqrt{ }$ & $\sqrt{ }$ & & & & & $\sqrt{ }$ & Malaysia & 2013 & 284 & $\begin{array}{l}\text { (Rosli \& Sidek, } \\
\text { 2013) }\end{array}$ \\
\hline
\end{tabular}


Jamai, De Steur, Abidar, Gellynck

\begin{tabular}{|c|c|c|c|c|c|c|c|c|c|c|c|c|}
\hline \multirow[t]{2}{*}{ Industry } & \multicolumn{5}{|c|}{$\begin{array}{l}\text { The innovation } \\
\text { involved }(*)\end{array}$} & \multicolumn{3}{|c|}{$\begin{array}{l}\text { Performance } \\
\text { indicators }(*)\end{array}$} & \multirow[t]{2}{*}{ Country } & \multirow[t]{2}{*}{$\begin{array}{c}\text { Year of } \\
\text { publication }\end{array}$} & \multirow[t]{2}{*}{ Sample } & \multirow[t]{2}{*}{ References } \\
\hline & $P d$ & $\operatorname{Pr}$ & Mr & Or & Uns & F. & N.F & Uns & & & & \\
\hline & & & & & $\sqrt{ }$ & $\sqrt{ }$ & & & $\begin{array}{c}\text { Germany, } \\
\text { Austria, } \\
\text { Switzer- } \\
\text { land }\end{array}$ & 2017 & 152 & $\begin{array}{l}\text { (Kallmuenzer } \\
\text { \& Scholl- } \\
\text { Grissemann, } \\
\text { 2017) }\end{array}$ \\
\hline & & & & & $\sqrt{ }$ & & & $\sqrt{ }$ & Malaysia & 2009 & 121 & (Man, 2009) \\
\hline & & & & $\sqrt{ }$ & & & $\sqrt{ }$ & & Australia & 2009 & 302 & $\begin{array}{l}\text { (O'Cass \& } \\
\text { Weerawardena, } \\
2009)\end{array}$ \\
\hline & $\sqrt{ }$ & & & & & & & $\sqrt{ }$ & US & 2016 & 169 & $\begin{array}{l}\text { (Roach et al., } \\
2016)\end{array}$ \\
\hline & $\sqrt{ }$ & $\sqrt{ }$ & & & & $\sqrt{ }$ & & & Korea & 2015 & -- & $\begin{array}{l}\text { (Hwang et al., } \\
2015 \text { ) }\end{array}$ \\
\hline & $\sqrt{ }$ & $\sqrt{ }$ & & & & & $\sqrt{ }$ & & Spain & 2008 & 1091 & $\begin{array}{l}\text { (Auken et al., } \\
2008)\end{array}$ \\
\hline & $\sqrt{ }$ & $\sqrt{ }$ & & & & $\sqrt{ }$ & & & India & 2011 & 157 & $\begin{array}{l}\text { (Subrahmanya, } \\
\text { 2011) }\end{array}$ \\
\hline & $\sqrt{ }$ & $\sqrt{ }$ & & & & $\sqrt{ }$ & & & US & 2006 & 182 & $\begin{array}{l}\text { (Wolff \& Pett, } \\
2006)\end{array}$ \\
\hline & $\sqrt{ }$ & & & & & & & $\sqrt{ }$ & Greece & 2008 & 128 & $\begin{array}{l}\text { (Salavou \& } \\
\text { Avlonitis, } \\
2008)\end{array}$ \\
\hline & $\sqrt{ }$ & $\sqrt{ }$ & $\sqrt{ }$ & $\sqrt{ }$ & & & & $\sqrt{ }$ & Zimbabwe & 2015 & 200 & $\begin{array}{l}\text { (Makanyeza \& } \\
\text { Dzvuke, 2015) }\end{array}$ \\
\hline & $\sqrt{ }$ & & & & & & $\sqrt{ }$ & & Indonesia & 2015 & 200 & $\begin{array}{l}\text { (Meutia, } \\
\text { 2015) }\end{array}$ \\
\hline & & & & & $\sqrt{ }$ & $\sqrt{ }$ & & & Mauritius & 2013 & 123 & $\begin{array}{l}\text { (Kasseeah, } \\
\text { 2013) }\end{array}$ \\
\hline & & & & & $\sqrt{ }$ & $\sqrt{ }$ & & & UAE & 2013 & 200 & $\begin{array}{l}\text { (Al-Ansari et } \\
\text { al., 2013) }\end{array}$ \\
\hline & & & & $\sqrt{ }$ & & & & $\sqrt{ }$ & Italy & 2011 & 114 & $\begin{array}{l}\text { (Della Torre \& } \\
\text { Solari, 2011) }\end{array}$ \\
\hline & $\sqrt{ }$ & $\sqrt{ }$ & $\sqrt{ }$ & $\sqrt{ }$ & & & & $\sqrt{ }$ & Malaysia & 2017 & 43 & $\begin{array}{l}\text { (Kim-Soon et } \\
\text { al., 2017) }\end{array}$ \\
\hline Service & $\sqrt{ }$ & & & & & $\sqrt{ }$ & & & Netherlands & 2005 & 502 & $\begin{array}{l}\text { (Vermeulen, } \\
\text { De Jong, \& } \\
\text { O'Shaughnessy, } \\
2005)\end{array}$ \\
\hline \multirow[t]{2}{*}{ Software } & & & & & $\sqrt{ }$ & & $\sqrt{ }$ & & Brazil & 2017 & 105 & $\begin{array}{l}\text { (Finoti, } \\
\text { Didonet, } \\
\text { Toaldo, \& } \\
\text { Martins, 2017) } \\
\end{array}$ \\
\hline & $\sqrt{ }$ & $\sqrt{ }$ & & & & & $\sqrt{ }$ & & Pakistan & 2014 & 124 & $\begin{array}{l}\text { (Ndubisi \& } \\
\text { Agarwal, } \\
\text { 2014) } \\
\end{array}$ \\
\hline Varied & $\sqrt{ }$ & $\sqrt{ }$ & & & & & & $\sqrt{ }$ & Turkish & 2011 & 270 & $\begin{array}{l}\text { (Ar \& Baki, } \\
\text { 2011) }\end{array}$ \\
\hline
\end{tabular}


Jamai, De Steur, Abidar, Gellynck

\begin{tabular}{|c|c|c|c|c|c|c|c|c|c|c|c|c|}
\hline \multirow[t]{2}{*}{ Industry } & \multicolumn{5}{|c|}{$\begin{array}{c}\text { The innovation } \\
\text { involved }(*)\end{array}$} & \multicolumn{3}{|c|}{$\begin{array}{l}\text { Performance } \\
\text { indicators }(*)\end{array}$} & \multirow[t]{2}{*}{ Country } & \multirow[t]{2}{*}{$\begin{array}{c}\text { Year of } \\
\text { publication }\end{array}$} & \multirow[t]{2}{*}{ Sample } & \multirow[t]{2}{*}{ References } \\
\hline & Pd & $\mathrm{Pr}$ & $\mathrm{Mr}$ & Or & Uns & $\mathbf{F}$. & N.F & Uns & & & & \\
\hline & $\sqrt{ }$ & $\sqrt{ }$ & & & & $\sqrt{ }$ & & & Italy & 2015 & 62 & $\begin{array}{l}\text { (Bartolacci et } \\
\text { al., 2014) }\end{array}$ \\
\hline & $\sqrt{ }$ & $\sqrt{ }$ & $\sqrt{ }$ & & & & $\sqrt{ }$ & & Malaysia & 2011 & 115 & $\begin{array}{l}\text { (Hilmi et al., } \\
2011)\end{array}$ \\
\hline & & & & & $\sqrt{ }$ & $\sqrt{ }$ & & & Australia & 2012 & 1435 & $\begin{array}{l}\text { (Gronum, } \\
\text { Verreynne, \& } \\
\text { Kastelle, } \\
\text { 2012) }\end{array}$ \\
\hline & $\sqrt{ }$ & $\sqrt{ }$ & & & & & & $\sqrt{ }$ & Malaysia & 2010 & 92 & $\begin{array}{l}\text { (Hilmi, } \\
\text { Ramayah, } \\
\text { Mustapha, \& } \\
\text { Pawanchik, } \\
\text { 2010) }\end{array}$ \\
\hline & $\sqrt{ }$ & $\sqrt{ }$ & & & & $\sqrt{ }$ & $\sqrt{ }$ & & UK & 2007 & 108 & $\begin{array}{l}\text { (Oke et al., } \\
2007)\end{array}$ \\
\hline & $\sqrt{ }$ & $\sqrt{ }$ & & & & $\sqrt{ }$ & & & Iran & 2018 & 197 & $\begin{array}{l}\text { (Saeidi, } \\
\text { Othman, } \\
\text { Saeidi, \& } \\
\text { Saeidi, 2018) }\end{array}$ \\
\hline & $\sqrt{ }$ & & & & & & $\sqrt{ }$ & & Japan & 2016 & 189 & $\begin{array}{l}\text { (Tajeddini, } \\
\text { 2016) }\end{array}$ \\
\hline & $\sqrt{ }$ & & & & & & & $\sqrt{ }$ & Italy & 2015 & 162 & $\begin{array}{l}\text { (Veglio \& } \\
\text { Zucchella, } \\
2015)\end{array}$ \\
\hline & & & & & $\sqrt{ }$ & & & $\sqrt{ }$ & Malaysia & 2013 & 284 & $\begin{array}{l}\text { Rosli \& } \\
\text { Mahmood, } \\
\text { 2013) }\end{array}$ \\
\hline & & & & & $\sqrt{ }$ & & & $\sqrt{ }$ & China & 2014 & 651 & $\begin{array}{l}\text { (Qiao, Ju, \& } \\
\text { Fung, 2014) }\end{array}$ \\
\hline & $\sqrt{ }$ & $\sqrt{ }$ & $\sqrt{ }$ & $\sqrt{ }$ & & & $\sqrt{ }$ & & Ghana & 2018 & 437 & $\begin{array}{l}\text { (Afriyie, Duo, } \\
\text { Appiah, \& } \\
\text { Musah, 2018) }\end{array}$ \\
\hline & $\sqrt{ }$ & $\sqrt{ }$ & & & & & $\sqrt{ }$ & & Pakistan & 2014 & 124 & $\begin{array}{l}\text { (Ndubisi \& } \\
\text { Agarwal, } \\
\text { 2014) }\end{array}$ \\
\hline
\end{tabular}

Note : $\left({ }^{*}\right)$ : Pd-Product, Pr-Process, Mr-Market, Or-Organizational, and Uns-Unspecified.

$(* *)$ : F-Financial, N.F-Non-financial, and Uns-Unspecified.

\section{Stream 2 : Most influential innovation types}

Based on the reviewed studies, innovation types can significantly and positively impact SMEs' performance. However, the magnitude of the effects differs from one industry to the other. Table 5 summarized impacts based on the regression analysis applied in the selected studies. Through the comparison of regression coefficients, clear differences were noticed between the industries, especially between the manufacturing, agro-food and manufacturing \& service industries, which 
behave differently.

Manufacturing industry: Within the Manufacturing industry, product innovation had the highest coefficient $(0,373 * *)$, allowing it to record superior performance (Roach et al., 2016; Rosli $\&$ Sidek, 2013). Surprisingly, process innovation got the lowest coefficient $\left(0,111^{* *}\right)$ even compared to the types of non-technological innovation. Indeed, compared to large companies, SMEs face several challenges in their innovation process, adversely affecting their innovation performance (Pullen, De Weerd-Nederhof, Groen, Song, \& Fisscher, 2009). Furthermore, comparison between the targeted industries indicated that for technological innovation, the manufacturing industry had the lowest value $\left(0.111^{* *}\right)$. The coefficient is particularly low for process innovation, which engages heavy investment and costs, which may explain its indistinct effect on firm performance (Fagerberg, 2013; Ndesaulwa \& Kikula, 2016). For non-technological innovation, the manufacturing industry obtained a similar ranking as for technological innovation, but slightly higher $\left(0,196^{*}\right)$ in the case of organizational innovation.

Agro-food industry: Within and across the studied industries, the agro-food industry registered the highest coefficient regarding the impact of product and marketing innovation on business performance $\left(4.31^{* *}, 1.23^{* *}\right)$ as an indicator of technological and non-technological innovation respectively (Alam et al., 2016). Marketing innovation has succeeded in the challenge of differentiating from the rest and achieving a high value, which was linked to an increase in sales of SMEs. Indeed, a development of clear strategy for market introduction, as well as selection and assessment of new ideas are behind new product success and consequently a significant effect on firm growth (Ernst, 2002; Kachouie \& Sedighadeli, 2015).

Manufacturing \& service industry: The manufacturing \& services industries recorded a much higher coefficient at the product innovation level $\left(0,541^{* *}\right)$. The particular characteristics of the service industry, chiefly its variability, intangibility and perishability (H. F. Lin, 2011), are potential underlying causes of this effect. In a similar vein, organizational innovation had the strongest effect on business performance compared to the other industries, which can be related to the importance of an adequate firm structure, administrative procedures, distribution of responsibility, and a well human resource management, especially in the service sector (Kim-Soon et al., 2017; Lalic, Anisic, Medić, Tasic, \& Marjanovic, 2018).

Other industries: Limited studies were done on SMEs in the remaining industries. For example, in the ceramic craft/stone industry, product innovation recorded a significant value, unlike the software industry where process innovation held the highest coefficient. A clear focus on technological innovation was noticed due to the facility to measure innovation performance when the indicators are tangible (Saunila, 2017). In the case of studies including different industries, one cannot easily select an innovation type that performs better concerning its influence on firm performance as all types have approximate coefficients. It can be distinguished that product and process innovation are the most influential indicators. However, non-technological innovation is ranked behind taking into account the difficulty of perceiving the direct effect of marketing and organizational actions on growth in the short term.

To summarize the obtained results, studies examining the manufacturing industry indicated that technological innovation and more specifically, product innovation strongly influenced the firm performance, which was confirmed by the findings in the manufacturing and service industry where product innovation had a robust impact on the performance. However, this latest industry was also impacted by organizational innovation providing evidence on the importance of non-technological innovation as a mechanism for firm improvement. Regarding the agro-food sector, product and marketing innovation were the types that most influenced the growth. The role played by marketing strategy in this sector was explicitly highlighting the dependence between marketing and product 
innovation to ensure firm success. For ceramic/craft and software sectors, studies were focused only on technological innovation, and showed that product innovation and process innovation were the most influencing types respectively. On the contrary, marketing innovation highly affected the performance of firms operating in the garment sector. Finally, studies dealing with varied sectors showed a major impact of technological innovation, with an insignificant difference between the product and process.

The analyzed results showed that until now, research is much more concentrated on studying the effect of technological innovation, in particular, product and process innovation to the deprivation of the other types also judged as source of performance and improvement of companies in the studies which covered them (Günday et al., 2011; Makanyeza \& Dzvuke, 2015). The results obtained confirmed the difference of innovation impact according to the targeted industrial sector and showed which type could be more beneficial to enhance firm performance.

\section{5. Conclusions}

As of today, innovation is still a complex phenomenon used by SMEs to face the market change in order to adapt to the external environment. In this scoping review, the aim was to explore current literature regarding the role played by industry when assessing the impact of innovation type on SMEs' performance. Findings demonstrate the difference in innovation influence according to the targeted industrial sector and show which type could be more beneficial to enhance firm performance.

From a theoretical perspective, this paper provides a compilation of existing literature. It shows that despite recent efforts made to examine the effects of non-technological innovation (marketing \& organizational), it is still understudied compared to technological innovation (Bocquet \& Dubouloz, 2020; Černe, Kaše, \& Škerlavaj, 2016; Djellal \& Gallouj, 2012). It also confirms that product innovation remains relevant for the majority of sectors as long as it rapidly generates growth and ensures high performance (Azambuja \& Machado, 2018). Furthermore, the study offers a comprehensive framework that can be used by managers and academics to determine the most used innovation type as well as the predominant indicators that strongly influence SMEs performance and can have more impact on their growth and continuity in the market. As was suggested in Becheikh et al. (2006)'s study and confirmed by Negassi, Lhuillery, Sattin, Hung, and Pratlong (2018)'s research, an examination of industry type as a variable that strongly distinguishes innovative firms from non-innovative firms will bring new insight. Given that companies in different sectors vary considerably with regard to their adopted innovation strategy and achieved business performance. The scoping review also gives a general overview of the industry type as an external factor playing a central role in impacting the innovation-performance relationship. It helps to select and measure some specific parameters related to innovation in order to develop effective managerial mechanisms by focusing on innovation types that provide relevant impact. Indeed, Kolluru and Mukhopadhaya (2017) asked for more robust results that can be generalized with regard to different sectors while examining the innovation-performance relationship, which was followed in this review. For academics, this framework provides foundations for future research to explore the understudied innovation type that was neglected by researchers or being sidelined to derive pertinent conclusions on the importance of such a type.

In terms of management, one can recommend that managers of SMEs adapt the best practice approaches to the identified industries (Geldes et al., 2016; Makanyeza \& Dzvuke, 2015). They should define and formulate a clear strategy and orientation before starting the creation and development of innovation. According to our findings; with the exception of the agro-food 


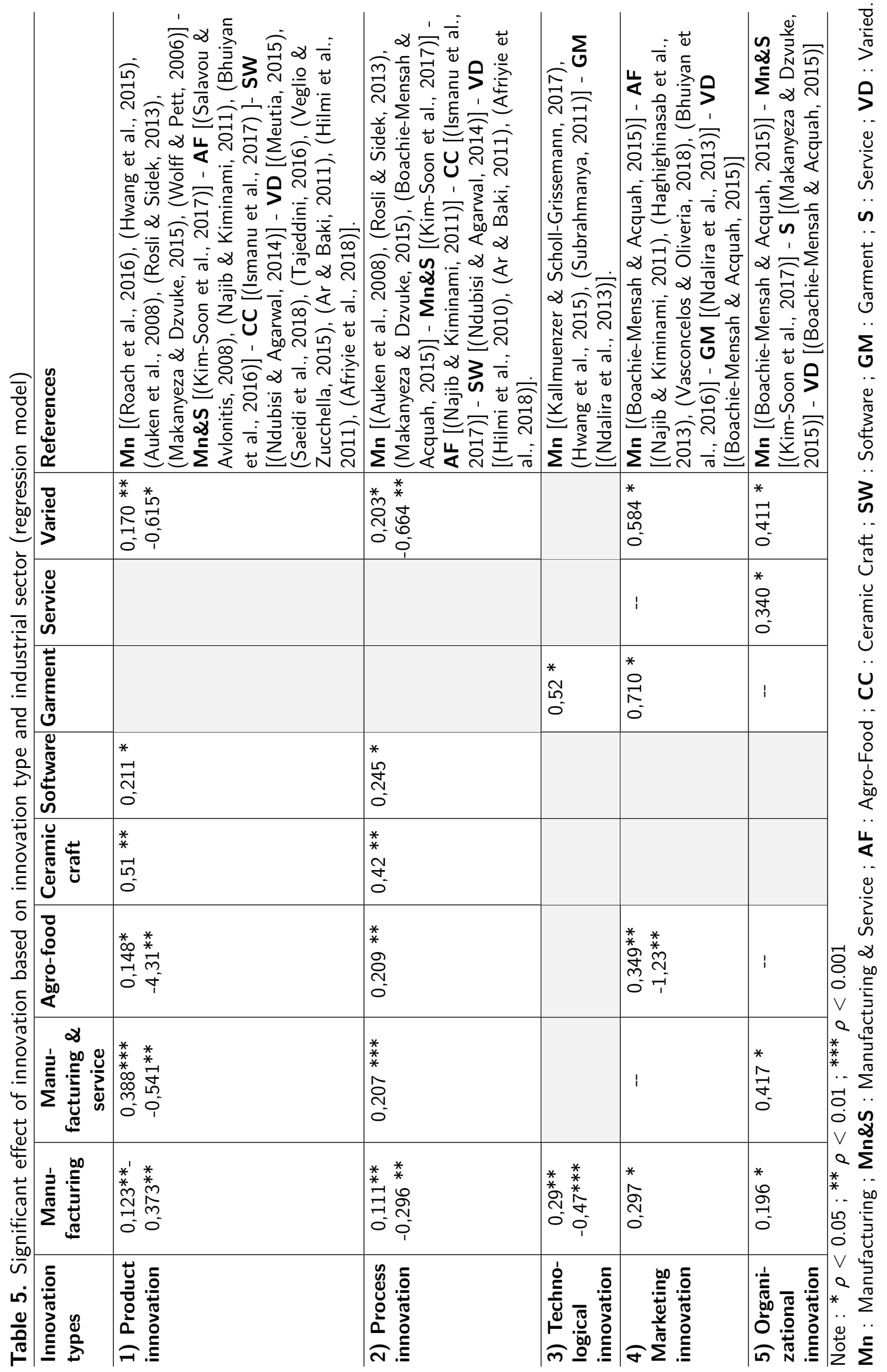


industry, we recommend to managers wishing to operate in the industries mentioned in this article mainly, manufacturing, Garment, Ceramic craft and Furniture, to seek competitiveness first on product and process innovation and to take financial performance as a key indicator. Through the adoption of an innovation type that provides a higher performance and ensures the improvement of their resources (Borowski, 2021; Kolluru \& Mukhopadhaya, 2017), managers can guarantee a stable environment and ecosystem since the effect will differ from one industry to the other. As for policymakers, several decisions can be taken to stimulate firms. They can encourage fair competitiveness in all industrial and service sectors to guarantee a healthy ecosystem. Similarly, a focus on the replication of the best practice in a different adapted version will offer the opportunity to examine the impact, compare it and measure growth. This scoping review gives a broad picture of innovative impacts and the industry as a variable influencing the effect intensity in the field of innovation performance. Firms and especially SMEs have to know the variables influencing their performance for faster growth to manage them effectively and adapt their work to gain market opportunities and benefit from external resources (Enjolras et al., 2019). Understanding the main drivers of innovation will be the key success of firms which can guide the way their business works.

Finally, it can be concluded that innovation is an essential factor for a firm (Allahar, 2019). Its impact can be different according to the industry and also the strength of some innovation types (Bach et al., 2019; Vasconcelos \& Oliveria, 2018). Even when innovation is not leading to the expected performance, it is still the engine of development and productivity (Kolluru \& Mukhopadhaya, 2017) because its effect can be perceived immediately in the short term and in the long term. Hence, to measure a firm's long term success, both financial and non-financial indicators should be included (Avci et al., 2011; Kotane, 2015).

\section{Futures research and limitations}

The study has some limitations. For instance, this review focused on SMEs only considered as a driver of economic development and a stimulator of growth and productivity in both developing and developed countries (Robson et al., 2009). Consequently, studies dealing with other sizes or working on companies, in general, were excluded. To this end, future reviews could focus on a comparison between SMEs and large firms to bring out the points of differences and similarities in the relationship. The study has put emphasis on comparing SMEs in specific industrial contexts. So as to reduce this gap, we recommend that future research considers a replication of this study in a different context which will provide more understanding of firms behavior. While a specific parameter has been used for mapping the performance, there can be more parameters in the financial context which might be relevant. Future research needs to also take into account all innovation types when studying their effect on firm performance and the combination that highly outperforms to get a complete understanding of the phenomenon. Based on the findings, non-technological innovations were understudied (Djellal \& Gallouj, 2012; Günday et al., 2011). Moreover, more research is needed to apply a comparison between the influence of technological and non-technological innovation through internal and external factors, mainly, industry type and firm size.

\section{Acknowledgments}

The study was funded by VLIR-UOS (MA2017TEA1444A103).

\section{Conflicts of Interest}

The authors declare no conflict of interest. 


\section{References}

Afriyie, S., Duo, J., Appiah, K., \& Musah, A.-A. I. (2018). The Nexus between Types of Innovation and Marketing Performance of Small Medium-sized Enterprises in an Emerging Economy International Review of Management and Marketing, 8(6), 78-92. doi:10.32479/irmm.7042

Al-Ansari, Y., Pervan, S., \& Xu, J. (2013). Innovation and business performance of SMEs: the case of Dubai. Education, Business and Society: Contemporary Middle Eastern Issues, 6(3/4), 162-180. doi:10.1108/ebs-04-2013-0012

Alam, S. S., Bhuiyan, A. B., Jani, F. M., \& Wel, C. A. C. (2016). The impact of innovation on growth and performance of processed food SMEs in Malaysia. International Journal of Entrepreneurship and Innovation Management, 20(1-2), 61-79. doi:https://doi.org/10.1504/IJEIM.2016.075299

Alegre, J., Sengupta, K., \& Lapiedra, R. (2013). Knowledge management and innovation performance in a high-tech SMEs industry. International Small Business Journal, 31(4), 454-470. doi:10.1177/0266242611417472

Allahar, H. (2019). A Management Innovation Approach to Project Planning. Technology Innovation Management Review, 9(6), 4-13. doi:10.22215/timreview/1245

Ar, I. M., \& Baki, B. (2011). Antecedents and performance impacts of product versus process innovation. European Journal of Innovation Management, 14(2), 172-206. doi:10.1108/14601061111124885

Arksey, H., \& O'Malley, L. (2005). Scoping studies: towards a methodological framework. International Journal of Social Research Methodology, 8(1), 19 - 32. doi:10.1080/1364557032000119616

Armstrong, R., Hall, B. J., Doyle, J., \& Waters, E. (2011). 'Scoping the scope' of a Cochrane review. Journal of Public Health, 33(1), 147-150. doi:10.1093/pubmed/fdr015

Astuti, M., Prawoto, P., Irawan, Y., \& Sugiono, S. (2018). The Eco-Innovation Variables which Influence the Performance of Creative Industries Center of Natural Stone Crafts. Journal of Ecological Engineering, 19(1), 14-24. doi:10.12911/22998993/79446

Auken, H. V., Guijarro, A. M., \& Lema, D. G. P. d. (2008). Innovation and performance in Spanish manufacturing SMEs. International Journal of Entrepreneurship and Innovation Management, 8(1). doi:10.1504/ijeim.2008.018611

Avci, U., Madanoglu, M., \& Okumus, F. (2011). Strategic orientation and performance of tourism firms: Evidence from a developing country. Tourism Management, 32(1), 147-157. doi:10.1016/j.tourman.2010.01.017

Azambuja, A. V., \& Machado, M. (2018). Product Innovation as a Competitive Advantage for Emerging Multinationals: The Case of the Judge Revolver in The USA. Review of International Business (Internext), 13(3), 1-13. doi:10.18568/1980-4865.1331-13

Bach, T. M., Dalazen, L. L., da Silva, W. V., Ferraresi, A. A., \& da Veiga, C. P. (2019). Relationship Between Innovation and Performance in Private Companies: Systematic Literature Review. SAGE Open, 9(2), 1-17. doi:10.1177/2158244019855847

Bartolacci, F., Castellano, N. G., \& Cerqueti, R. (2014). The impact of innovation on companies' performance: an entropy-based analysis of the STAR market segment of the Italian Stock Exchange. Technology Analysis \& Strategic Management, 27(1), 102-123. doi:10.1080/09537325.2014.952624

Becheikh, N., Landry, R., \& Amara, N. (2006). Lessons from innovation empirical studies in the manufacturing sector: A systematic review of the literature from 1993-2003. Technovation, 
26(5-6), 644-664. doi:10.1016/j.technovation.2005.06.016

Belotti, V. N., Santos, D. F. L., \& Basso, L. F. C. (2019). METHODOLOGY FOR ASSESSING RISK IN INNOVATION INVESTMENTS. REVISTA DE ADMINISTRAÇÃO DA UFSM, 12(5), 953-974. doi:10.5902/ 1983465924401

Beyene, K. T., Shi, C. S., \& Wu, W. W. (2016). The impact of innovation strategy on organizational learning and innovation performance: Do firm size and ownership type make a difference? South African Journal of Industrial Engineering, 27(1), 125-136. doi:10.7166/27-1-1308

Bhaskaran, S. (2006). Incremental Innovation and Business Performance: Small and Medium-Size Food Enterprises in a Concentrated Industry Environment. Journal of Small Business Management, 44(1), 64-80. doi: https://doi.org/10.1111/j.1540-627X.2006.00154.x

Bhuiyan, A. B., Said, J., Ismail, M. D., Jani, M. F. M., \& Fie, D. Y. G. (2016). The innovation drivers, strategies and performance of food processing SMEs in Malaysia. Malaysian Journal of Society and Space, 12(2), 154 - 166.

Bigliardi, B. (2014). The effect of innovation on financial performance: A research study involving SMEs. Innovation: Management, Policy \& Practice, 15(2), 245-255. doi:10.5172/impp.2013.15.2.245

Bigliardi, B., Ferraro, G., Filippelli, S., \& Galati, F. (2020). The influence of open innovation on firm performance. International Journal of Engineering Business Management, 12, 1-14. doi:10.1177/1847979020969545

Birchall, A., Carnegie, T., Draimin, T., Elkington, J., \& Love, C. (2014). Breaking through: How corporate social innovation creates business opportunity. Retrieved from. Retrieved from http://www.kpmg. com/Ca/en/IssuesAndInsights/ArticlesPublications/Documents/5441-KPMGSocial- Innovation-Report-FY14-web-Final.pdf

Boachie-Mensah, F., \& Acquah, I. S. K. (2015). The Effect of Innovation Types on the Performance of Small and Medium-Sized Enterprises in the Sekondi-Takoradi Metropolis. Archives of Business Research, 3(3), 77-98. doi:10.14738/abr.33.1240

Bocquet, R., \& Dubouloz, S. (2020). Firm Openness and Managerial Innovation: Rebalancing Deliberate Actions and Institutional Pressures. [Firm Openness and Managerial Innovation: Rebalancing Deliberate Actions and Institutional Pressures]. Journal of Innovation Economics \& Management, 32(2), 43-74. doi:10.3917/jie.032.0043

Borowski, P. F. (2021). Innovation strategy on the example of companies using bamboo. Journal of Innovation and Entrepreneurship, 10(1), 1-17. doi:10.1186/s13731-020-00144-2

Cacchione, P. Z. (2016). The Evolving Methodology of Scoping Reviews. Clinical Nursing Research, 25(2), 115-119. doi:10.1177/1054773816637493

Cành, N. T., Liem, N. T., Thu, P. A., \& Khuong, N. V. (2019). The Impact of Innovation on the Firm Performance and Corporate Social Responsibility of Vietnamese Manufacturing Firms. Sustainability, 11(13), 3666. doi:10.3390/su11133666

Černe, M., Kaše, R., \& Škerlavaj, M. (2016). Non-technological innovation research: evaluating the intellectual structure and prospects of an emerging field. Scandinavian Journal of Management, 32(2), 69-85. doi:https://doi.org/10.1016/j.scaman.2016.02.001

Chatzoglou, P., \& Chatzoudes, D. (2018). The role of innovation in building competitive advantages: an empirical investigation. European Journal of Innovation Management, 21(1), 44-69. doi:10.1108/ejim-02-2017-0015 
Chen, G. (2017). Research on Innovation Driving Force and Industrial Upgrading under Information Technology. Paper presented at the International Conference on Organizational Innovation (ICOI 2017).

Costa, E. D. O., Cabral, J. E. O., Forte, S. H. A. C., \& Costa, M. d. P. B. (2016). Patterns of Technological Innovation: A Comparative Analysis between Low-tech and High-tech Industries in Brazil. International Journal of Innovation, 4(2), 97-111. doi:10.5585/iji.v4i2.101

Damanpour, F. (1991). Organizational Innovation: A Meta-Analysis of Effects of Determinants and Moderators. The Academy of Management Journal, 34(3), 555-590. doi:DOI: 10.2307/256406

De Man, A.-P., \& Duysters, G. (2005). Collaboration and innovation: a review of the effects of mergers, acquisitions and alliances on innovation. Technovation, 25(12), 1377-1387. doi:10.1016/j.technovation.2004.07.021

Della Torre, E., \& Solari, L. (2011). High performance work systems, technological innovations and firm performance in SME: evidences from Italy. International Journal of Entrepreneurial Venturing, 3(4), 375-391. doi:10.1504/ijev.2011.043384

Djellal, F., \& Gallouj, F. (2012). Social Innovation and Service Innovation. In In Challenge social innovation (pp. 119-137). Berlin, Heidelberg: Springer, .

Enjolras, M., Camargo, M., \& Schmitt, C. (2019). Are High-Tech Companies More Competitive Than Others? An Empirical Study of Innovative and Exporting French SMEs. Technology Innovation Management Review, 9(1), 33-49. doi:10.22215/timreview/1210

Ernst, H. (2002). Success Factors of New Product Development: A Review of the Empirical Literature. International Journal of Management Reviews, 4(1), 1-40. doi:https://doi.org/10.1111/14682370.00075

Fagerberg, J. (2013). Innovation - a New Guide. Oslo : Centre for Technology, Innovation and Culture, University of Oslo. Retrieved from https://ideas.repec.org/p/tik/inowpp/20131119.html

Finoti, L., Didonet, S. R., Toaldo, A. M., \& Martins, T. S. (2017). The role of the marketing strategy process in the innovativeness-performance relationship of SMEs. Marketing Intelligence \& Planning, 35(3), 298-315. doi:10.1108/mip-01-2016-0005

Forsman, H., \& Temel, S. (2011). Innovation And Business Performance In Small Enterprises: An Enterprise-Level Analysis. International Journal of Innovation Management, 15(3), 641-665. doi:10.1142/S1363919611003258

Forth, J., \& Bryson, A. (2018). The Impact of Management Practices on SME Performance. Bonn, Germany: Institute of Labor Economics (IZA).

Gardner, K., Kearns, R., Woodland, L., Silveira, M., Hua, M., Katz, M., . . . McDonald, J. (2018). A Scoping Review of the Evidence on Health Promotion Interventions for Reducing Waterpipe Smoking: Implications for Practice. Frontiers in Public Health, 6(308), 1-13. doi:10.3389/fpubh.2018.00308

Gatautis, R., Vaiciukynaite, E., \& Tarutè, A. (2019). Impact of business model innovations on SME's innovativeness and performance. Baltic Journal of Management. doi:10.1108/BJM-012018-0035

Geldes, C., Felzensztein, C., \& Palacios-Fenech, J. (2016). Technological and non-technological innovations, performance and propensity to innovate across industries: The case of an emerging economy. Industrial Marketing Management, 61, 1-12. doi:10.1016/j.indmarman.2016.10.010 
Gronum, S., Verreynne, M. L., \& Kastelle, T. (2012). The Role of Networks in Small and MediumSized Enterprise Innovation and Firm Performance. Journal of Small Business Management, 50(2), 257-282. doi: https://doi.org/10.1111/j.1540-627X.2012.00353.x

Guan, J., \& Pang, L. (2017). Industry specific effects on innovation performance in China. China Economic Review, 44, 125-137. doi:https://doi.org/10.1016/j.chieco.2017.03.013

Günday, G., Ulusoy, G., Kılıç, K., \& Alpkan, L. (2011). Effects of innovation types on firm performance. International Journal of Production Economics, 133, 662-676. doi:10.1016/j.ijpe.2011.05.014

Haghighinasab, M., Sattari, B., Ebrahimi, M., \& Roghanian, P. (2013). The Effect of Channel Function Performance on Relationship Quality with Organizational Buyers:A Case Study in Iranian Food Distribution Company. International Journal of Fundamental Psychology and Social Sciences, 3(3), 42-47. doi:10.14331/ijfpss.2013.330033

Hajar, I. (2015). The Effect of Business Strategy on Innovation and Firm Performance in the Small Industrial Sector. The International Journal Of Engineering And Science, 4(2), 01-09

Herrera, M. E. B. (2016). Innovation for impact: Business innovation for inclusive growth. Journal of Business Research, 69(5), 1725-1730. doi:10.1016/j.jbusres.2015.10.045

Higgins, J. M. (1995). Innovation: The core competence. Planning Review, 23(6), 32-36. doi:10.1108/eb054532

Hilmi, M. F., Ramayah, T., \& Mustapha, Y. (2011). Innovativeness and Performance of Small and Medium Enterprises: Malaysian Perspectives. International Journal of Knowledge, Culture and Change Management, 10(12), 105-114.

Hilmi, M. F., Ramayah, T., Mustapha, Y., \& Pawanchik, S. (2010). Product and Process Innovativeness: Evidence from Malaysian SMEs. European Journal of Social Sciences, 16(10), 556-565.

Hinteregger, C., Durst, S., Temel, S., \& Yesilay, R. (2019). The impact of poness on innovation in SMEs. International Journal of Innovation Management, 23(1), 1950003-1950001-11950031950030. doi:10.1142/S1363919619500038

Ho, K. L. P., Nguyen, C. N., Adhikari, R., Miles, M. P., \& Bonney, L. (2018). Exploring market orientation, innovation, and financial performance in agricultural value chains in emerging economies. Journal of Innovation \& Knowledge, 3(3), 154-163. doi:https://doi.org/10.1016/j.jik.2017.03.008

Hossain, M. (2015). A review of literature on open innovation in small and medium-sized enterprises. Journal of Global Entrepreneurship Research, 5(1), 1-12. doi:10.1186/s40497-015-0022-y

Huiban, J.-P., \& Bouhsina, Z. (1998). Innovation and the quality of labour factor: An empirical investigation in the French food industry. Small Business Economics, 10(4), 389-400. doi:https://doi.org/10.1023/A:100796741

Hwang, Y.-S., Hwang, M.-H., \& Dong, X. (2015). The Relationships Among Firm Size, Innovation Type, and Export Performance With Regard to Time Spans. Emerging Markets Finance and Trade, 51(5), 947-962. doi:10.1080/1540496x.2015.1061386

lonescu, A., \& Dumitru, N. R. (2015). The role of innovation in creating the company's competitive advantage. Ecoforum Journal, 4(1), 99-104.

Ismanu, S., Salim, U., Moeljadi, G., \& Aisjah, S. (2017). The Effect of Innovation Strategy on Financial Performance Small and Medium Enterprises in Indonesia. International Journal of 
Applied Business and Economic Research, 15(22), 365-379.

Kachouie, R., \& Sedighadeli, S. (2015). NEW PRODUCT DEVELOPMENT SUCCESS FACTORS in PROSPECTOR ORGANISATIONS; MIXED METHOD APPROACH. International Journal of Innovation Management, 19(4), 1550040-1550041-1550040-1550023.

doi:10.1142/S1363919615500401

Kallmuenzer, A., \& Scholl-Grissemann, U. (2017). Disentangling antecedents and performance effects of family SME innovation: A knowledge-based perspective. International Entrepreneurship and Management Journal, 13(4), 1117-1138. doi:10.1007/s11365-017-0443-x

Karno, C. G., \& Purwanto, E. (2017). The Effect of Cooperation and Innovation on Business Performance. Calitatea, 18(158), 123-126.

Kasseeah, H. (2013). Innovation and performance in small- and medium-sized enterprises: evidence from Mauritius. Innovation and Development, 3(2), 259-275. doi:10.1080/2157930x.2013.825069

Kim-Soon, N., Ahmad, A. R., Kiat, C. W., \& Sapry, H. R. (2017). SMES Are Embracing Innovation for Business Performance. Journal of Innovation Management in Small and Medium Enterprises, 1-17. doi:10.5171/2017.824512

King, S., \& Grobbelaar, S. S. (2020). Industry 4.0 and Business Model Innovation: A Scoping Review. Paper presented at the In 2020 IEEE International Conference on Engineering, Technology and Innovation (ICE/ITMC), Cardiff, UK.

Klewitz, J., \& Hansen, E. G. (2014). Sustainability-oriented innovation of SMEs: a systematic review. Journal of cleaner production, 65, 57-75. doi:10.1016/j.jclepro.2013.07.017

Kolluru, S., \& Mukhopadhaya, P. (2017). Empirical Studies on Innovation Performance in the Manufacturing and Service Sectors Since 1995: A Systematic Review. Economic Papers: A journal of applied economics and policy, 36(2), 223-248. doi:10.1111/1759-3441.12167

Kotane, I. (2015). Evaluating the importance of financial and non-financial indicators for the evaluation of compan ${ }^{\mathrm{TM}} \mathrm{s}$ performance. Management Theory and Studies for Rural Business and Infrastructure Development, 37(1), 80-94. doi:10.15544/mts.2015.08

Kotha, S., \& Nair, A. (1995). Strategy and Environment as Determinants of Performance: Evidence from the Japanese Machine Tool Industry. Strategic Management Journal, 16(7), 497-518. doi:10.1002/SMJ.4250160702

Lalic, B., Anisic, Z., Medić, N., Tasic, N., \& Marjanovic, U. (2018). THE IMPACT OF ORGANIZATIONAL INNOVATION CONCEPTS ON NEW PRODUCTS AND RELATED SERVICES. DEStech Transactions on Engineering and Technology Research, 110-115. doi:10.12783/dtetr/icpr2017/17593 Lichtenthaler, U. (2020). Agile Innovation: The Complementarity of Design Thinking and Lean Startup. International Journal of Service Science, Management, Engineering, and Technology (IJSSMET), 11(1), 157-167. doi:10.4018/IJSSMET.2020010110

Lin, C. Y. Y., \& Chen, M. Y. C. (2007). Does innovation lead to performance? An empirical study of SMEs in Taiwan. Management Research News, 30(2), 115-132. doi:10.1108/01409170710722955

Lin, F. J., Chen, Y. M., \& Lo, F. Y. (2014). The persistence of economic profit. International Entrepreneurship and Management Journal, 10(4), 767-780. doi:10.1007/s11365-013-0248-5

Lin, H. F. (2011). An empirical investigation of mobile banking adoption: The effect of innovation attributes and knowledge-based trust. International Journal of Information Management, 31(3), 
252-260. doi:https://doi.org/10.1016/j.ijinfomgt.2010.07.006

Lumpkin, G. T., \& Dess, G. G. (1996). Clarifying the entrepreneurial orientation construct and linking it to performance. Academy of Management Review, 21(1), 135-172. doi:DOI: $10.2307 / 258632$

Mai, A. N., Van Vu, H., Bui, B. X., \& Tran, T. Q. (2019). The lasting effects of innovation on firm profitability: panel evidence from a transitional economy. Economic Research-Ekonomska Istraživanja, 32(1), 3417-3436. doi:10.1080/1331677X.2019.1660199

Makanyeza, C., \& Dzvuke, G. (2015). The influence of innovation on the performance of small and medium enterprises in Zimbabwe. Journal of African Business, 16(1-2), 198-214. doi:10.1080/15228916.2015.1061406

Man, M. M. K. (2009). The Relationship Between Distinctive Capabilities, Innovativeness, Strategy Types And The Performance Of Small And Medium-Size Enterprises (SMEs) Of Malaysian Manufacturing Sector. International Business \& Economics Research Journal, 8(11), 205-223. doi:10.19030/iber.v8i11.3182

Manual, O. (1992). Proposed Guidelines for Collecting and Interpreting Technological Innovation Data: OECD, Paris.

Manual, O. (1997a). Proposed Guidelines for Collecting and Interpreting Technological Innovation Data : OECD, Paris.

Manual, O. (1997b). Proposed Guidelines for Collecting and Interpreting Technological Innovation Data: (Second (Revised) Edition). OECD, Paris. .

Manual, O. (2005). Oslo Manual: Guidelines for Collecting and Interpreting Innovation Data, 3rd Edition, The Measurement of Scientific and Technological Activities, OECD Publishing, Paris.

Manual, O. (2019). Promoting innovation in established SMEs, Strengthening SMEs and Entrepreneurship for Productivity and Inclusive Growth : OECD Paris.

Martins, J. M., Abreu, A., \& Calado, J. (2018). The Need to Develop a Corporate Culture of Innovation in a Globalization Context. In In Globalization (pp. 1-17): IntechOpen.

Meutia. (2015). The relationship between entrepreneurship social competence and marketing performance in Indonesian SMEs: the role of business networking and product innovation. International Journal of Applied Business and Economic Research, 13(7), 5357-5373.

Munn, Z., Peters, M. D., Stern, C., Tufanaru, C., McArthur, A., \& Aromataris, E. (2018). Systematic review or scoping review? Guidance for authors when choosing between a systematic or scoping review approach. BMC Medical Research Methodology, 18(1), 19-28. doi:10.1186/s12874018-0611-x

Najib, M., \& Kiminami, A. (2011). Innovation, cooperation and business performance, Some evidence from Indonesian small food processing cluster. Journal of Agribusiness in Developing and Emerging Economies, 1(1), 75-96. doi:10.1108/20440831111131523

Naoui-Outini, F., \& El Hilali, N. (2019). Innovative suppliers and purchasing function interaction: An exploratory research in the car rental sector. [Innovative suppliers and purchasing function interaction: An exploratory research in the car rental sector]. Journal of Innovation Economics \& Management, 28(1), 171-192. doi:10.3917/jie.028.0165

Ndalira, D. W., Ngugi, J. K., \& Chepkulei, B. (2013). Effect of the type of innovation on the 
growth of small and medium enterprises in Kenya: a case of garment enterprises in Jericho, Nairobi. European Journal of Management Sciences and Economics, 1(2), 49-57.

Ndesaulwa, A. P., \& Kikula, J. (2016). The Impact of Innovation on Performance of Small and Medium Enterprises (SMEs) in Tanzania: A Review of Empirical Evidence. Journal of Business and Management Sciences, 4(1), 1-6. doi:10.12691/jbms-4-1-1

Ndubisi, N., \& Agarwal, J. (2014). Quality performance of SMEs in a developing economy: Direct and indirect effects of service innovation and entrepreneurial orientation. The Journal of Business and Industrial Marketing, 29(6), 454-468. doi:10.1108/JBIM-07-2013-0146

Negassi, S., Lhuillery, S., Sattin, J. F., Hung, T. Y., \& Pratlong, F. (2018). Does the relationship between innovation and competition vary across industries? Comparison of public and private research enterprises. Economics of Innovation and New Technology, 28(2), 465-482. doi:10.1080/10438599.2018.1527552

Norrman, C., \& Bager-Sjögren, L. (2010). Entrepreneurship policy to support new innovative ventures: Is it effective? International Small Business Journal, 28(6), 602-619.

doi:10.1177/0266242610369874

Nuryanti, S., \& Andreas, P. (2018). The effect of knowledge management, innovation and learning organization on business performance and competitive advantage of Small and Medium Enterprises Riau Food products in Pekanbaru city. International Journal of Scientific \& Technology Research, 7(4), 260-267.

O'Cass, A., \& Weerawardena, J. (2009). Examining the role of international entrepreneurship, innovation and international market performance in SME internationalisation. European Journal of Marketing, 43(11/12), 1325-1348. doi:10.1108/03090560910989911

Oke, A., Burke, G., \& Myers, A. (2007). Innovation types and performance in growing UK SMEs. International Journal of Operations \& Production Management, 27(7), 735-753. doi:DOI 10.1108/01443570710756974

Ortiz-Villajos, J. M., \& Sotoca, S. (2018). Innovation and business survival: A long-term approach. Research policy, 47(8), 1418-1436. doi:10.1016/j.respol.2018.04.019

Otero-Neira, C., Tapio Lindman, M., \& J. Fernández, M. (2009). Innovation and performance in SME furniture industries. Marketing Intelligence \& Planning, 27(2), 216-232.

doi:10.1108/02634500910944995

Peters, M. D., Godfrey, C. M., Khalil, H., Mclnerney, P., Parker, D., \& Soares, C. B. (2015). Guidance for conducting systematic scoping reviews. International journal of evidence-based healthcare, 13(3), 141-146. doi:10.1097/XEB.0000000000000050

Pham, M. T., Rajić, A., Greig, J. D., Sargeant, J. M., Papadopoulos, A., \& McEwen, S. A. (2014). A scoping review of scoping reviews: advancing the approach and enhancing the consistency. Research synthesis methods, 5(4), 371-385. doi:10.1002/jrsm.1123

Prifti, R., \& Alimehmeti, G. (2017). Market orientation, innovation, and firm performance---an analysis of Albanian firms. Journal of Innovation and Entrepreneurship, 6(8), 1-19. doi:10.1186/s13731017-0069-9

Pullen, A., De Weerd-Nederhof, P., Groen, A., Song, M., \& Fisscher, O. (2009). Successful Patterns of Internal SME Characteristics Leading to High Overall Innovation Performance. Wiley-Blackwell: Creativity \& Innovation Management, 18(3), 209-223. doi:10.1111/j.1467-8691.2009.00530.x 
Qiao, P. H., Ju, X. F., \& Fung, H. G. (2014). Industry association networks, innovations, and firm performance in Chinese small and medium-sized enterprises. China Economic Review, 29, 213-228. doi:10.1016/j.chieco.2014.04.011

Ratshidi, L., Grobbelaar, S., \& Botha, A. (2020). Categorization of Factors Influencing Community Health Workers from a Socio-Technical Systems Perspective. In Responsible Design, Implementation and Use of Information and Communication Technology (Vol. 12067, pp. 84-95).

Rexhepi , L. (2014). The impact of innovation in SME's performance. Horizons INTERNATIONAL SCIENTIFIC JOURNAL, 12, 195-206.

Riaz, M. S. (2016). Naturalistic Behaviour Observation of Road Users: A Scoping Review. (Master of Transportation Sciences-Traffic Safety), Universiteit Hasselt, Belgium. Retrieved from http://hdl.handle.net/1942/22284

Roach, D. C., Ryman, J. A., \& Makani, J. (2016). Effectuation, innovation and performance in SMEs: an empirical study. European Journal of Innovation Management, 19(2), 214-238. doi:10.1108/ejim-12-2014-0119

Robson, P. J. A., Haugh, H. M., \& Obeng, B. A. (2009). Entrepreneurship and innovation in Ghana: enterprising Africa. Small Business Economics, 32(3), 331-350 doi:DOI 10.1007/s11187008-9121-2

Romano, C. A. (1990). Identifying Factors Which Influence Product Innovation: A Case Study Approach. Journal of Management Studies, 27(1), 75-95. doi:https://doi.org/10.1111/j.14676486.1990.tb00754.x

Rosli, M. M., \& Mahmood, R. (2013). Moderating Effects of Human Resource Management Practices and Entrepreneur Training on Innovation and Small-Medium Firm Performance. Journal of Management and Strategy, 4(2), 60-69. doi:10.5430/jms.v4n2p60

Rosli, M. M., \& Sidek, S. (2013). The Impact of Innovation on the Performance of Small and Medium Manufacturing Enterprises: Evidence from Malaysia. Journal of Innovation Management in Small \& Medium Enterprise, 1-16. doi:10.5171/2013.885666

Rubera, G., \& Kirca, A. (2012). Firm Innovativeness and Its Performance Outcomes: A MetaAnalytic Review and Theoretical Integration. Journal of Marketing, 76, 130-147.

doi: $10.2307 / 41714493$

Saeidi, S. P., Othman, M. S. H., Saeidi, P., \& Saeidi, S. P. (2018). The moderating role of environmental management accounting between environmental innovation and firm financial performance. International Journal of Business Performance Management, 19(3), 326-348. doi:10.1504/IJBPM.2018.092759

Salavou, H., \& Avlonitis, G. (2008). Product innovativeness and performance: a focus on SMEs. Management Decision, 46(7), 969-985. doi:10.1108/00251740810890168

Saunila, M. (2017). Understanding innovation performance measurement in SMEs. Measuring Business Excellence, 21(1), 1-16. doi:10.1108/MBE-01-2016-0005

Sethibe, T., \& Steyn, R. (2015). The relationship between leadership styles, innovation and organisational performance: A systematic review. South African Journal of Economic and Management Sciences, 18(3), 325-337. doi:10.17159/2222-3436/2015/v18n3a3

Shouyu, C. (2017). The Relationship between Innovation and Firm Performance: A Literature Review. . Advances in Computer Science Research, 82. doi:DOI: 10.2991/snce-17.2017.132 
Spanos, Y. E., \& Lioukas, S. (2001). An Examination into the Causal Logic of Rent Generation: Contrasting Porter's Competitive Strategy Framework and the Resource-Based Perspective. Strategic Management Journal, 22(10), 907-934. doi:10.1002/smj.174

Spies, R., Grobbelaar, S., \& Botha, A. (2020). A Scoping Review of the Application of the TaskTechnology Fit Theory. Implementation and Use of Information and Communication Technology, 12066, 397-408. doi:10.1007/978-3-030-44999-5_33

Spithoven, A., Vanhaverbeke, W., \& Roijakkers, N. (2013). Open innovation practices in SMEs and large enterprises. Small Business Economics, 41(3), 537-562. doi:10.1007/s11187-012-9453-9

Subrahmanya, M. H. B. (2011). Technological Innovations and Firm Performance of Manufacturing SMEs: Determinants and Outcomes. ASCI Journal of Management, 41(1), 109-122.

Tajeddini, K. (2016). Financial Orientation, Product Innovation and Firm Performance: An Empirical Study in the Japanese SMEs. International Journal of Innovation and Technology Management, 13(3), 1640005-1640001-1640005-1640030. doi:10.1142/S0219877016400058

Tan, Y. (2016). Chapter 3 - Theory of Bank Efficiency and Bank Competition. In Y. Tan (Ed.), Efficiency and Competition in Chinese Banking (pp. 45-66): Chandos Publishing.

Tavassoli, S. (2015). Innovation determinants over industry life cycle. Technological Forecasting and Social Change, 91, 18-32. doi:https://doi.org/10.1016/j.techfore.2013.12.027

Tether, B. S., \& Tajar, A. (2008). The Organisational-Cooperation Mode of Innovation and Its Prominence amongst European Service Firms. Research policy, 37(4), 720-739.

Tricco, A. C., Lillie, E., Zarin, W., O'Brien, K., Colquhoun, H., Levac, D., . . . Straus, S. (2018). PRISMA extension for scoping reviews (PRISMA-ScR): Checklist and explanation. Annals of Internal Medicine, 169(7), 467-473. doi:10.7326/M18-0850

Tricco, A. C., Soobiah, C., Antony, J., Cogo, E., MacDonald, H., Lillie, E., . . . Kastner, M. (2016). A scoping review identifies multiple emerging knowledge synthesis methods, but few studies operationalize the method. Journal of Clinical Epidemiology, 73, 19-28. doi:https://doi.org/10.1016/j.jclinepi.2015.08.030

Tuan, N., Nhan, N., Giang, P., \& Ngoc, N. (2016). The effects of innovation on firm performance of supporting industries in Hanoi, Vietnam. Journal of Industrial Engineering and Management, 9(2), 413-431. doi:10.3926/jiem.1564

Urbancova, H. (2013). Competitive Advantage Achievement through Innovation and Knowledge. Journal of Competitiveness, 5(1), 82-96. doi:10.7441/joc.2013.01.06

van Niekerk, L., Manderson, L., \& Balabanova, D. (2021). The application of social innovation in healthcare: a scoping review. Infectious Diseases of Poverty, 10(1), 1-25. doi:10.1186/s40249021-00794-8

Vasconcelos, R., \& Oliveria, M. (2018). Does innovation make a difference? Innovation \& Management Review, 15(2), 137-154. doi:10.1108/inmr-04-2018-011

Veglio, V., \& Zucchella, A. (2015). Entrepreneurial firms in traditional industries. Does innovation matter for international growth? Journal of International Entrepreneurship, 13(2), 138-152. doi:10.1007/s10843-015-0142-z

Vermeulen, P. A. M., De Jong, J. P. J., \& O'Shaughnessy, K. C. (2005). Identifying key determinants for new product introductions and firm performance in small service firms. The 
Service Industries Journal, 25(5), 625-640. doi:10.1080/02642060500100783

Walker, R. M., Chen, J., \& Aravind, D. (2015). Management innovation and firm performance: An integration of research findings. European Management Journal, 33(5), 407-422. doi:10.1016/j.emj.2015.07.001

Wolff, J. A., \& Pett, T. L. (2006). Small-Firm Performance: Modelling the Role of Product and Process Improvements. Journal of Small Business Management, 44(2), 268-284. doi: https://doi.org/10.1111/j.1540-627X.2006.00167.x

YuSheng, K., \& Ibrahim, M. (2020). Innovation Capabilities, Innovation Types, and Firm Performance: Evidence From the Banking Sector of Ghana. SAGE Open, 10(2), 1-12.

doi:10.1177/2158244020920892

Zahra, S. A., \& Nielsen, A. P. (2002). Sources of capabilities, integration and technology commercialization. Strategic Management Journal, 23(5), 377-398. doi:10.1002/smj.229

Zawislak, P. A., Gamarra, J. T., Alves, A. C., Barbieux, D., \& Reichert, F. M. (2014). The different innovation capabilities of the firm: further remarks upon the Brazilian experience. Journal of Innovation Economics \& Management, 13(1), 129-150. doi:10.3917/jie.013.0129 


\section{Biographies}

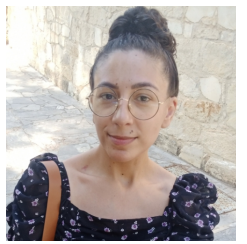

Kaoutar Jamai. Jamai Kaoutar is a Ph.D. student in the Agricultural Economics Department at Ghent University -Belgium-. After completing in 2013, her engineering degree in the National School of Agriculture of Meknès -Morocco-in the field of rural development and economic studies, she worked as an agricultural marketing consultant in a private cabinet. Between 2013-2016, she developed more than 30 business plans and feasibility studies for national and international companies, and also a great expertise in value chains of collaborative projects for small producers. In 2016 she joined Attijariwafa bank, the first banking and financial group in Morocco as a junior business manager. This time, however, to evaluate jointly with the risk department the business plans of agri-business investors. Both experiences triggered in her the desire to embark on a Ph.D. study. Since her first registration, she published an article entitled:" Consumer's Behavior and Preferences towards Olive Oil in Morocco: The Case of Meknes-Fes Region" (Journal of Engineering, 2019). She participated in several international symposiums and she is assisting her co-supervisor in Morocco in some students' activities such as their final project/internship.

CRediT Statement: Conceptualization - Data curation - Analysis - Methodology - Resources - Visualization Writing the original draft - Writing - review \& editing.

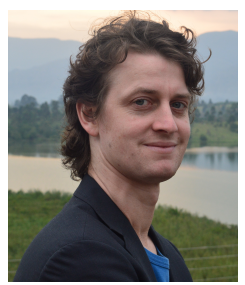

Hans De Steur. Prof. dr. Hans De Steur is currently assistant professor in quantitative research methods in socio-economics at the Division of Agri-food Marketing \& Chain Management, Department of Agricultural Economics, Ghent University. He holds a master degree in Sociology as well as in Economics and Business Administration (both at Ghent University). In 2011, he successfully finished his $\mathrm{PhD}$ at the Faculty of Bioscience Engineering. His current research is situated in the field of agri-food marketing and agricultural economics, with a focus on consumer, stakeholder and impact analysis of innovations and technologies. He was and is involved in various multidisciplinary research projects and has with various publications in top-tier journals in different research domains.

CRediT Statement: Supervision, Validation, Correcting the original draft, Remarks \& suggestions.

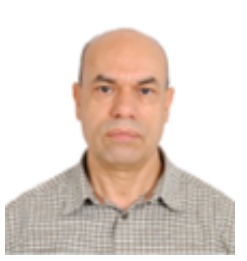

Ali Abidar. Abidar Ali is a professor of food marketing in the Department of Rural Development Engineering at the National School of Agriculture (Morocco). He graduated from the National School of Agriculture with an engineering diploma in agricultural economics in 1992. For two years, he served as the interim Deputy Director of Research, Cooperation, and Partnership. In 2000, He obtained his PhD from the Faculty of Bioscience Engineering at Ghent University Belgium-. He devoted a significant time working on the field as part of national and international research and action programs.

CRediT Statement: Supervision, Validation, Remarks \& Suggestions.

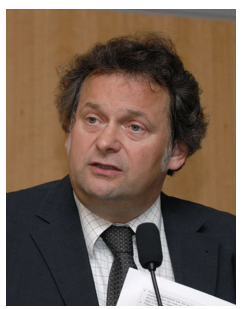

Xavier Gellynck. Professor Gellynck graduated as a Master of Science in Industrial Economics at Ghent University, Belgium in 1987. In 1989, he obtained a MBA-degree in Marketing Management of Service Industries from the Business School IAAE at the University of AixMarseille in France. Since 2002, he works as a professor at Ghent University, Faculty of Bioscience Engineering, Department Agricultural Economics. He holds a PhD in Business Economics and leads a research group of about 25 researchers. His main fields of research interest are situated in the domain of agri-business marketing and value chain \& network management. He was also the founder and chairman of the board of management of Afoheat NV, a food machinery construction company. He is a member of the board of management of the cooperative bank Crelan NV and Europabank. Prof. Gellynck is author of over 300 scientific publications.

CRediT Statement: Supervision. 